Review

\title{
Function and Regulation of MicroRNAs and Their Potential as Biomarkers in Paediatric Liver Disease
}

\author{
Diego A. Calvopina ${ }^{1}$, Miranda A. Coleman ${ }^{1}$, Peter J. Lewindon ${ }^{1,2,3}$ and Grant A. Ramm ${ }^{1,3, *}$ \\ 1 Hepatic Fibrosis Group, QIMR Berghofer Medical Research Institute, 300 Herston Rd, Herston, QLD 4006, \\ Australia; Diego.Calvopina@qimrberghofer.edu.au (D.A.C.); \\ Miranda.Coleman@qimrberghofer.edu.au (M.A.C.); Peter.Lewindon@health.qld.gov.au (P.J.L.) \\ 2 Department of Gastroenterology and Hepatology, Lady Cilento Children's Hospital, 501 Stanley St, \\ South Brisbane, QLD 4101, Australia \\ 3 Faculty of Medicine and Biomedical Sciences, The University of Queensland, Brisbane, QLD 4006, Australia \\ * Correspondence: Grant.Ramm@qimrberghofer.edu.au; Tel.: +61-733-620-177
}

Academic Editor: Y-h. Taguchi

Received: 12 September 2016; Accepted: 20 October 2016; Published: 27 October 2016

\begin{abstract}
MicroRNAs (miRNAs) are short non-coding RNAs involved in biological and pathological processes of every cell type, including liver cells. Transcribed from specific genes, miRNA precursors are processed in the cytoplasm into mature miRNAs and as part of the RNA-induced silencing complex (RISC) complex binds to messenger RNA (mRNA) by imperfect complementarity. This leads to the regulation of gene expression at a post-transcriptional level. The function of a number of different miRNAs in fibrogenesis associated with the progression of chronic liver disease has recently been elucidated. Furthermore, miRNAs have been shown to be both disease-and tissue-specific and are stable in the circulation, which has led to increasing investigation on their utility as biomarkers for the diagnosis of chronic liver diseases, including those in children. Here, we review the current knowledge on the biogenesis of microRNA, the mechanisms of translational repression and the use of miRNA as circulatory biomarkers in chronic paediatric liver diseases including cystic fibrosis associated liver disease, biliary atresia and viral hepatitis B.
\end{abstract}

Keywords: microRNA; children; chronic liver disease; circulatory miRNA

\section{Introduction}

In the US alone around 15,000 children are hospitalized for liver disease each year [1], however, the relative lack of epidemiological research studies in children masks the true prevalence of chronic liver disease which is likely underestimated. In fact, paediatric liver disease has an important impact on health care costs, leads to premature deaths and impacts quality of life in affected children.

Paediatric liver diseases are often diagnosed late, mainly due the lack of symptoms during early stages of the disease. The diagnosis is increasingly challenging when symptoms are non-specific such as loss of appetite, abdominal pain or fatigue. Liver biopsy remains the "gold standard" for diagnosis of liver disease and detection of hepatic fibrosis. However, liver biopsy is an invasive technique with potential for severe complication including bleeding, biliary peritonitis and pain. Moreover, liver biopsy is limited by sampling only a small part of the liver leading to sampling and diagnostic errors in liver disorders with a heterogeneous disease distribution. These issues highlight the need for non-invasive diagnostic methods to directly assess liver diseases and the degree of hepatic fibrosis. MicroRNAs (miRNAs) are considered as potential biomarkers for several chronic disorders due to their stability in the circulation, and are both disease- and tissue-specific, which makes them attractive circulatory biomarkers.

miRNAs are short interfering RNAs which catalytically silence gene expression at a posttranscriptional level. They constitute the most abundant class of endogenous, small, non-coding 
RNA with approximately 50,000 copies per cell in the liver [2]. Since Ambros' discovery in 1993 [3], miRNAs have been extensively studied due to their role in RNA-induced silencing. In 2000, the miRNA let-7 was identified [4]. In contrast to previous miRNAs described, let-7 was shown to be widely conserved across different animal species [5]. This breakthrough discovery started an intensive search for novel miRNAs conserved over different species, including humans [2,6-8].

miRNAs are involved in the regulation of all biological and pathological processes in every cell type, including liver cells. Further, altered expression of miRNAs correlate with different liver aetiologies or are involved in the broader fibrogenic response to liver damage. The expression profiles of miRNAs also seem to be specific when compared between liver diseases of different aetiologies.

This review explores the current knowledge about the biogenesis of miRNAs, their regulation of gene expression, target identification and application as biomarkers in chronic paediatric liver disease.

\section{Biogenesis of miRNAs}

Mature miRNAs are single stranded RNAs of about 17-24 nucleotides (nt) which interact with RNA-induced silencing complex (RISC) in the cytoplasm of eukaryotic cells [9]. The pathway leading to this regulatory interaction and the steps involved in biogenesis of miRNA are depicted in Figure 1. miRNAs are encoded by specific genes transcribed by RNA Pol II into polyadenylated and capped stem-loop transcripts termed primary miRNAs (pri-miRNAs) [10,11]. Most miRNA genes encode a single miRNA, however, some are encoded in clusters and can include up to six miRNAs with a similar sequence [12]. A minority of miRNAs are located in introns of coding genes which form miRNA precursors during splicing [13]. miRNA biogenesis is regulated at a transcriptional and post-transcriptional level and single nucleotide polymorphisms (SNPs) in miRNA genes can modulate activity and function [14].

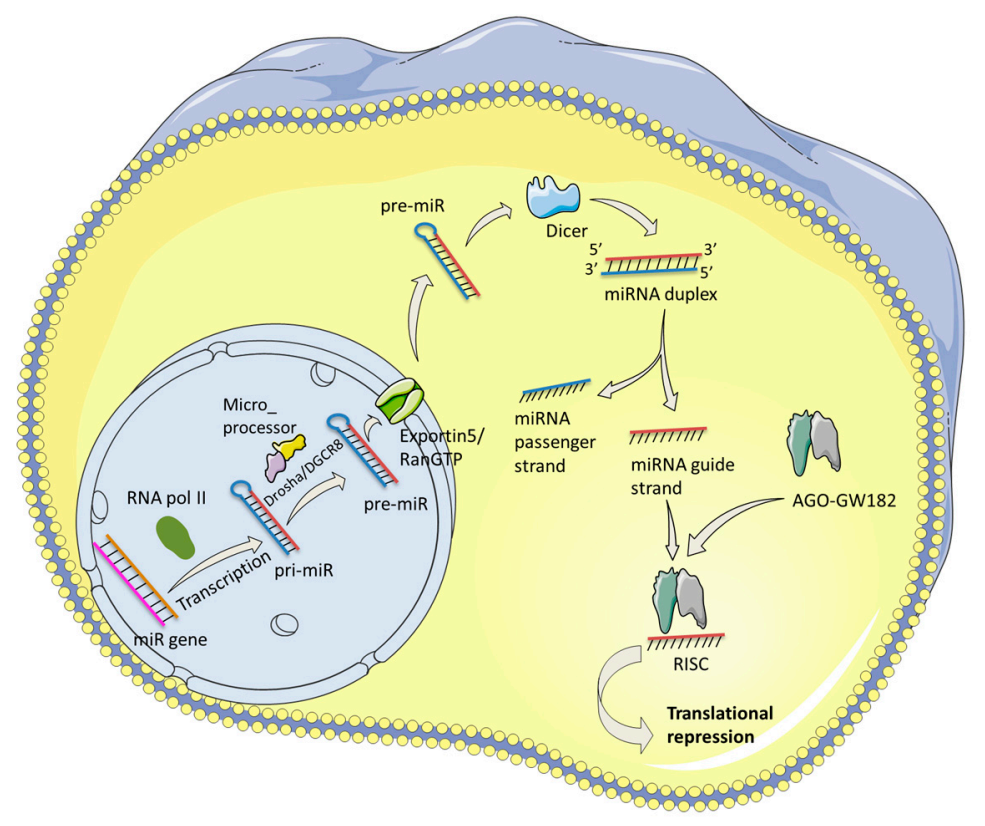

Figure 1. miRNA biogenesis. miRNAs are transcribed from miRNA genes by RNA pol II into pri-miRNA and cleaved by the microprocessor. The resulting pre-miRNA is exported to the cytoplasm by the exportin 5/RanGTP complex. Once in the cytoplasm, the endoribonuclease Dicer cleaves the pre-miRNA into a miRNA duplex. The mature miRNA is loaded into the AGO/GW182 complex forming the RISC complex, which mediates the translational repression. RNA pol II: RNA polymerase II; pri-miR: primary miRNA; pre-miRNA: precursor miRNA; AGO: argonaute; RISC: RNA-induced silencing complex. 
pri-miRNA undergoes a process of maturation in the nucleus, mediated by a complex called Microprocessor. The Microprocessor is formed by RNase III endonuclease Drosha and RNA-binding protein DGCR8 $[15,16]$. Drosha cuts the stem loop of the pri-miRNA, releasing a hairpin shaped RNA of 60-70 nt with a two nucleotide $3^{\prime}$ overhang named precursor miRNA (pre-miRNA) [17].

Once Drosha has processed pre-miRNA, it is exported to the cytoplasm by a complex composed of exportin 5 and the GTP-binding nuclear protein RanGTP [18,19]. In the cytoplasm, pre-miRNA is processed by the RNase III endonuclease called Dicer [20,21]. Dicer recognizes the $5^{\prime}$ phosphate and $3^{\prime}$ overhang at the base of the stem loop and cuts both RNA strands, liberating a mature miRNA with $5^{\prime}$ phosphate and two nucleotide $3^{\prime}$ overhang on each end of the double stranded RNA [22,23]. The mature miRNA processed by Dicer consists of a guide strand, which is antisense to the target sense strand on mRNA, and an unstable passenger strand.

The recently formed mature miRNA is loaded onto a protein called Argonaute (AGO) which is a family of four members [24]. This interaction forms an effector complex known as RNA-induced silencing complex (RISC) $[25,26]$. AGO proteins present a PAZ domain in the N-terminal lobe which binds to single stranded and duplex RNA $[27,28]$.

Assembly of RISC involves two steps: the binding of miRNA duplex and its unwinding [29]. In humans there is no strict RNA sorting system as in other species such as Drosophila [30]. RNA binds to any of the four AGO proteins with preference of small RNA duplexes with central mismatches between nucleotides in position 8-11 [31,32]. Once the RNA duplex is bound to an AGO protein, the passenger strand is removed to generate the mature and functional RISC complex [25]. This process is mediated by $\mathrm{AGO} 2$ which has helicase and endonuclease activity [33]. The guide strand presents mismatches at positions $2-8$ and $12-15 \mathrm{nt}$ that promote the unwinding of the duplex [31,34].

\section{Mechanisms of Translational Repression}

Efficient translation occurs when mRNAs possess a $5^{\prime}$-cap (5'-7-methylguanine or m7GpppN) and a $3^{\prime}$-poly(A) tail. During translation initiation, the cytoplasmic poly(A) binding protein (PABPC) associates with the poly(A) tail and acts together with the eukaryotic translation-initiation factor $4 \mathrm{G}$ (eIF4G). At the same time, eIF4G interacts with the $5^{\prime}$-cap structure, forming a circular mRNA that is protected from degradation and can be effectively translated [35,36] (Figure 2a). miRNAs interfere with the function and interaction of PABPC and eIF4G, inhibiting translation at the initial stage [37,38]. However, there are several mechanisms by which miRNAs may cause mRNA repression including a cap-independent mechanism, $5^{\prime}-3^{\prime}$ mRNA decay pathway, formation of pseudo-polysomes and ribosome drop-off model (Figure 2).

In cap-independent mRNA, miRNAs can silence translation through an internal ribosome entry site (IRES) [38,39] (Figure 2b). GW182 protein is part of the RISC complex that mediates translational repression. Once the target is identified by the miRNA within the RISC complex, GW182 interacts with PABPC (Figure 2c). The activated GW182 recruits the CAF1-CCR4-NOT deadenylase complex which deadenylates the mRNA [40-42]. After deadenylation, the mRNA is decapped by decapping enzyme DCP2 [43]. The deadenylated and decapped mRNA is then degraded by the cytoplasmic $5^{\prime}-3^{\prime}$ exonuclease XRN1 [44]. This process is known as the $5^{\prime}-3^{\prime}$ mRNA decay pathway [45] (Figure 2c).

Another model of repression has been described in Drosophila in which pseudo-polysomes are assembled from large miRNAs and mRNA forming a dense messenger ribonucleoprotein (mRNPs) complex heavier than the $80 \mathrm{~s}$ ribosome (Figure 2d) [46]. Pseudo-polysomes interact with structures called P-bodies that reside in the cytoplasm of eukaryotic cells and have been linked to mRNA degradation $[47,48]$. During the ribosome drop-off model, the interaction between ribosomes and mRNA is released when miRNA from the RISC complex binds the $3^{\prime} \mathrm{UTR}$ of the mRNA [38] (Figure 2e). Evidence for the existence of this model has been shown in polypeptides that undergo translation and are rapidly degraded under the regulation of specific miRNAs in contrast to inhibition at initial stages [49]. 

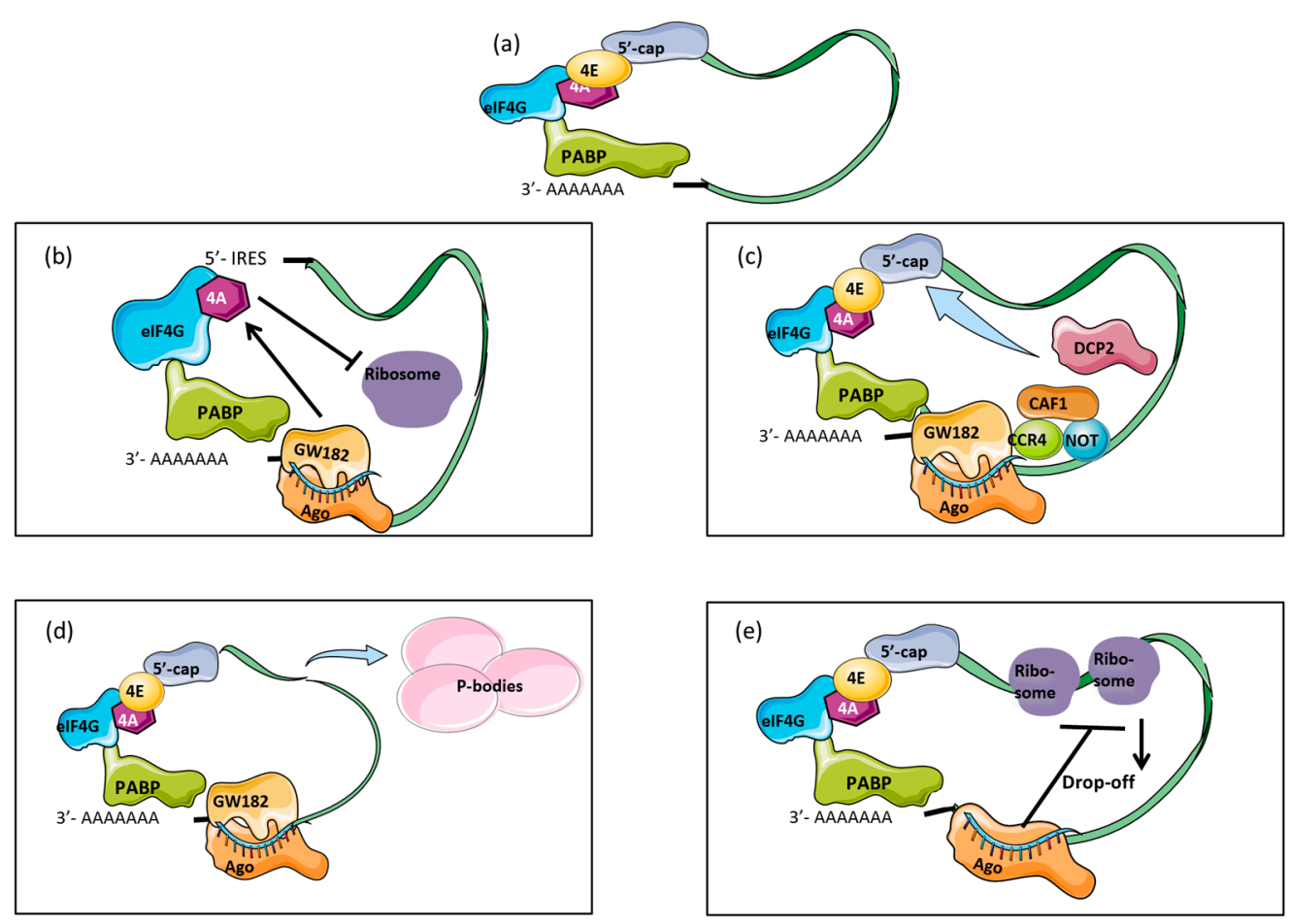

Figure 2. miRNA methods of translational repression. (a) mRNA is effectively translated when it possesses a $5^{\prime}$-cap and $3^{\prime}$-poly(A) tail. At the initiation of translation, PABP associates with eIF4G which interacts with the $5^{\prime}$-cap structure forming a circular mRNA protected from degradation; (b) In the cap-independent mechanism, IRES binds to EIF4G without the need of EIF4E. After miRNA-mRNA binding, translational repression is mediated by EIF4A on the $5^{\prime}$ UTR preventing the action of ribosomes; (c) During the $5^{\prime}-3^{\prime}$ decay pathway, GW182 as part of RISC, interacts with PABP and recruits the CAF1-CCR4-NOT complex which deadenylates mRNA. After deadenylation, mRNA is decapped by DCP2 and finally degraded; (d) mRNA degradation associated to p-bodies occurs after binding of RISC containing the miRNA. mRNA is sequestered to cytoplasmic P-bodies, which are centres of mRNA degradation containing key proteins necessary for translational repression; (e) In the ribosome drop-off model, miRNA associated with Argonaute binds to the mRNA target and has a distanced effect on translating ribosomes at multiple sites causing the ribosomes to drop-off. eIF4: eukaryotic translation-initiation factor 4; PABP: cytoplasmic poly(A) binding protein; IRES: internal ribosome entry site; DCP2: decapping enzyme 2.

\section{4. miRNA Target Identification}

For all of the aforementioned translational repression models, identification of the target mRNA by the miRNA within the RISC complex is essential. Watson-Crick base pairing of the nucleotides on the $5^{\prime}$ end of the miRNA and the target mRNA take place during this interaction [50-52]. The region in which mRNA and miRNA hybridization occurs is termed the "seed" sequence [50,53] and consists of a minimum of six base pairs (bp) which correspond to nucleotides $2-7$ from the $5^{\prime}$ end of the miRNA ( $3^{\prime}$ UTR of the mRNA). The seed sequence can be up to $8 \mathrm{bp}$ in length, based on the homology at position eight or the presence of an adenine (A) at nucleotide position one of the target mRNA [53].

However, seed matching alone is not enough to identify validated targets [54]. The context in which seed matching occurs plays an important role in determining miRNA targets in the canonical $3^{\prime}$ UTR or different segments of the mRNA. Grimson et al. [54] described the characteristics of the most common miRNA targets (Table 1). These parameters have been implemented in computational tools and algorithms that predict miRNA targets. 
Table 1. Parameters for the identification of miRNA targets.

\begin{tabular}{c} 
Parameters \\
\hline Closely spaced miRNAs often act synergistically \\
Watson-Crick pairing at nucleotide 12-17nt in addition to seed match enhanced miRNA targeting \\
Effective targets reside within locally AU-rich context \\
Effective targets reside in $3^{\prime}$ UTR strand but not close to stop codon \\
Effective sites preferentially reside near both ends of the $3^{\prime}$ UTR \\
\hline
\end{tabular}

miRNA downstream targets have been the focus of many animal studies designed to elucidate their involvement in fibrogenesis associated with chronic liver disease (reviewed elsewhere [55]). Only recently with interest in miRNAs as circulatory biomarkers have miRNAs been correlated with fibrosis in chronic liver diseases of varying aetiologies such as alcoholic liver disease (ALD) [56,57], non-alcoholic fatty liver disease (NAFLD) [58-61], chronic hepatitis C [58,62,63], chronic hepatitis B [64,65] or drug induced liver injury [66] to name a few. Most of these studies assessing the circulatory miRNA signature have been conducted in adult chronic liver diseases with a paucity of information available in the paediatric setting.

\section{Circulatory miRNAs as Biomarkers of Disease}

miRNAs finely adjust rather than completely repress gene expression [67]. It is estimated that most genes expressed in mammals [68] are to some extent regulated by the 2588 mature miRNAs identified to date [69]. Many biological pathways are regulated by miRNAs including cellular proliferation, differentiation, apoptosis, cell cycle regulation and development. Furthermore, the roles of miRNAs have been described in several diseases, including cancers [70-73], coronary diseases [74-76], autoimmune diseases [77-79] or viral infections such as viral hepatitis [80-83]. miRNAs predominantly exist intracellularly, however, it is possible to find miRNAs in extracellular environments such as in serum, plasma, semen, cerebrospinal fluid and urine [84-91]. Two hypotheses are proposed to explain the origin of circulatory miRNAs. The first suggests cells evolved to selectively release miRNAs via paracrine or endocrine routes to mediate cell-cell signalling [92,93]. The second proposes that miRNAs are released in a non-selective manner after cell death, correlating with increased levels of miRNAs in blood after toxicity in certain organs [57,94,95]. Circulatory miRNAs are relatively stable, especially compared with extracellular RNAs. miRNAs are packed in vesicles or in association with RNA binding proteins to prevent digestion by ribonucleases (RNases) [96].

The transfer of miRNA packed into extracellular vesicles (EVs) strengthens the hypothesis of direct cell-cell contact and selective release as a mechanism of intercellular communication. This enables miRNAs to regulate cell function in a paracrine manner or through the circulation and in different body fluids to reach cells in distal organs [97]. The term exosome was first used in 1983 referring to EVs [98]. Exosomes are formed in endosomal compartments called multivesicular endosomes (MVEs) by budding of the internal vesicle that contains proteins, mRNA and miRNA from the cell cytoplasm. Exosomes are actively secreted by fusion of the MVE with the plasma membrane (exosome biogenesis reviewed in [99]).

The different steps of MVE formation are highly regulated and include segregation of cargo, delimitation of the endosome membrane and the budding of vesicles in the endosome. The endosomal sorting complex required for transport (ESCRT) recognizes ubiquinated proteins and promotes their internalization into the MVEs during its formation [100]. Exosomes have a mean size of 40-100 nm [101]. To purify exosomes, a series of centrifugation and ultracentrifugation steps are used [102]. However, other EVs can be isolated along with exosomes and establishing methods for exosome purification based on size, density, morphology and membrane and protein composition remains a challenge [103].

Increasing interest in exosomes as disease biomarkers began a decade ago when Valadi et al. [93] reported that exosomes isolated from cultured cells contained both miRNA and mRNA. Furthermore, Valadi et al. showed that the mRNA was effectively and functional translated once the exosome was 
internalized in the target cell. This study was followed by reports of miRNA in exosomes isolated from different body fluids including blood and saliva [104-106]. Studies have revealed a distinctive miRNA profile in exosomes when compared to the miRNA profile of the cells from which the exosomes were formed $[107,108]$. This suggests that miRNAs are selectively incorporated into exosomes and not as a consequence of apoptosis or degradation of cellular components.

How miRNAs are sorted into exosomes remains unclear. Specific sequence motifs shared by miRNAs in EVs have been suggested to control their sorting into exosomes [109]. Moreover, it has been proposed that the heterogeneous nuclear ribonucleoprotein A2B1 (hnRNPA2B1) recognizes these specific miRNA motifs and controls their loading into exosomes [110]. Additionally, the presence of GW182 and AGO2 proteins in exosomes [111], both key molecules necessary for the RISC formation, suggests their potential role in exosome miRNA sorting although the precise mechanisms responsible remain to be elucidated.

Evidence suggests that released exosomes interact with specific target cells $[112,113]$. Target cell specificity depends on distinctive molecules including integrins [114], tetraspanin complexes [115] and others such as galactin-5 and galectin-9 [116]. After binding with the target cell, exosomes fuse with the plasma membrane and release their contents into the cytoplasm. Alternatively, exosomes have been shown to be internalized via endocytosis where they fuse with the endosomal membrane releasing their contents and/or be targeted for lysosomal degradation.

Regardless of the origin of circulatory miRNAs, their presence in readily accessible body fluids clearly make miRNAs attractive biomarker candidates. The ideal biomarker should meet stringent criteria, such as being disease-specific, detected in a non-invasive manner, an indicator of disease at an early stage, or responsive through the progression of the disease or treatment. miRNAs are indeed disease- and tissue-specific, stable in circulation and capable of distinguishing between healthy and diseased individuals, further strengthening the attraction of circulating miRNAs as biomarkers [117].

\section{Methodological Challenges in the Study of Circulatory miRNAs}

Pre-analytical variation can affect the quantification of miRNAs. During sample collection it is essential to remove cellular components such as erythrocytes, leukocytes and platelets from blood. In particular, erythrocytes express high levels of miR-451 and miR-16, which correlates with haemolysis in plasma samples [118,119]. Heparin, a traditional anticoagulant used in plasma, shows a dose dependent inhibitory effect by binding to calcium and magnesium used in PCR reactions [120,121]. Although miRNAs are resilient in serum or plasma, repeated freeze-thaw cycles decreases detectable miRNA levels and should be avoided [122].

One major challenge is the relatively low abundance of miRNA in plasma and serum along with high levels of proteins and lipids which can interfere with the isolation process. Originally, TRIzol was used as an effective method for small RNA isolation, however, phenol contamination and difficulty with pellet resuspension regularly interfered with the process. These problems have been partially solved by method modifications including small RNA binding columns common to multiple commercial kits.

Traditional RNA quantification methods, such as spectrophotometer or capillary electrophoresis, are unable to assess size or quality of the isolated miRNA accurately, due to the low yield and limits of detection. Quantitative reverse transcription-PCR (qRT-PCR) is currently considered the gold standard method for assessing isolated miRNA [119,123].

\section{Circulatory miRNAs as Biomarkers in Paediatric Liver Disease}

Several studies have explored the potential targets and thus the mechanistic role of specific miRNAs in chronic liver diseases, including those affecting children (Table 2). These studies have used liver tissue from children or animal models to identify miRNA expression profiles in the context of the specific disease. Once miRNAs of interest had been selected, liver and biliary cell lines were used to identify potential gene targets and their effect on protein synthesis, mRNA expression or 
the role they play in cellular biological pathways including proliferation, migration or apoptosis. These studies not only show the importance of gene regulation through miRNA in liver disease, but also the complex mechanisms that drive fibrosis in which miRNAs also play an important role. For instance, miR-122 has been the subject of extensive investigation in liver disease. miR-122 knockdown experiments in mice demonstrated important hepatopathological effects as mice aged including hepatocyte proliferation, imbalance in cellular differentiation and ductular reaction [124]. Similarly, multiple studies have shown increased serum levels of miR-122 corresponding to different liver aetiologies, suggesting that upregulation of miR-122 in serum may be a global marker of liver injury rather than disease-specific $[57,58,125,126]$. These evident roles for miRNAs in physiological and pathological pathways and their reflection in the circulation could be utilised for the non-invasive detection of chronic liver diseases in children.

Table 2. Functional miRNA studies in paediatric liver diseases.

\begin{tabular}{|c|c|c|c|c|c|}
\hline Disease & Sample Type & Sample Source & Upregulated & Downregulated & References \\
\hline \multirow{6}{*}{$\begin{array}{l}\text { Billiary atresia } \\
\text { (BA) }\end{array}$} & $\begin{array}{l}\text { Extrahepatic bile } \\
\text { ducts }\end{array}$ & mice & - & $\begin{array}{l}\mathrm{miR}-30 \mathrm{~b} / \mathrm{c} \\
\mathrm{miR}-133 \mathrm{a} / \mathrm{b} \\
\mathrm{miR}-195 \\
\mathrm{miR}-200 \mathrm{a} \\
\mathrm{miR}-320 \\
\mathrm{miR}-365\end{array}$ & Bessho et al. [127] \\
\hline & $\begin{array}{l}\text { LX2 (cell line) Liver } \\
\text { tissue }\end{array}$ & human & miR-200b & - & Xiao et al. [128] \\
\hline & Liver tissue & human & miR-21 & - & Shen et al. [129] \\
\hline & Liver tissue & mice & $\begin{array}{l}\operatorname{miR}-21 \\
\text { miR-29b1 } \\
\text { miR-29a }\end{array}$ & - & Hand et al. [130] \\
\hline & Liver tissue & mice & miR222 & - & Shen et al. [131] \\
\hline & Liver tissue & human & miR-222 & - & Dong et al. [132] \\
\hline \multirow[b]{2}{*}{$\begin{array}{l}\text { Cholestatic liver } \\
\text { injuries }\end{array}$} & $\begin{array}{l}\text { H69 and HIBEpiC } \\
\text { (cell lines) }\end{array}$ & human & miR-221 & - & Hu et al. [133] \\
\hline & Liver tissue & Human rat & $\begin{array}{l}\text { miR-200a } \\
\text { miR-141 } \\
\text { miR-200b } \\
\text { miR-200c }\end{array}$ & miR-124 & Xiao et al. [134] \\
\hline \multirow{3}{*}{$\begin{array}{l}\text { Acute liver } \\
\text { failure (ALF) }\end{array}$} & $\begin{array}{l}\text { Liver tissue } \\
\text { BNLCL2 (cell line) }\end{array}$ & mice & - & miR-1187 & Yu et al. [135] \\
\hline & $\begin{array}{l}\text { Liver tissue } \\
\text { BNLCL2 (cell line) }\end{array}$ & mice & $\begin{array}{l}\text { miR-155 } \\
\text { miR-125a/b } \\
\text { miR-26b } \\
\text { miR-15b } \\
\text { miR-16 } \\
\text { miR-21 }\end{array}$ & $\begin{array}{l}\mathrm{miR}-466 \mathrm{f} \\
\mathrm{miR}-467 \mathrm{f} \\
\mathrm{miR}-574 \\
\mathrm{miR}-93 \\
\mathrm{miR}-1187 \\
\text { miR-145 } \\
\text { let-7b } \\
\text { miR-329 } \\
\text { miR-24 }\end{array}$ & An et al. [136] \\
\hline & $\begin{array}{l}\text { Liver tissue HUH-7 } \\
\text { (cell line) }\end{array}$ & $\begin{array}{l}\text { human (adult } \\
\text { and children) }\end{array}$ & $\begin{array}{l}\text { miR-126 } \\
\text { miR-130a } \\
\text { miR-20a } \\
\text { miR-520e } \\
\text { miR-330 } \\
\text { miR-150 } \\
\text { let-7i } \\
\text { miR-27a } \\
\text { miR-494 } \\
\text { miR-1224 } \\
\text { miR-149 }\end{array}$ & $\begin{array}{l}\text { miR-503 } \\
\text { miR-23a } \\
\text { miR-663 } \\
\text { miR-654 } \\
\text { miR-152 } \\
\text { miR-200b } \\
\text { miR-183 }\end{array}$ & Salehi et al. [137] \\
\hline
\end{tabular}


Table 2. Cont.

\begin{tabular}{llllll}
\hline Disease & Sample Type & Sample Source & Upregulated & Downregulated & References \\
\hline & $\begin{array}{l}\text { Liver tissue HepG2 } \\
\text { (cell line) }\end{array}$ & $\begin{array}{l}\text { mice (liver) } \\
\text { human (cell line) }\end{array}$ & - & miR-451 & Hur et al. [138] \\
\cline { 2 - 6 } $\begin{array}{l}\text { Non-alcoholic } \\
\text { fatty liver disease } \\
\text { (NAFLD) }\end{array}$ & $\begin{array}{l}\text { Liver tissue HepG2 } \\
\text { (cell line) }\end{array}$ & $\begin{array}{l}\text { mice (liver) } \\
\text { human (cell line) }\end{array}$ & $\begin{array}{l}\text { miR-200a } \\
\text { miR-200c } \\
\text { miR-146a } \\
\text { miR-146b } \\
\text { miR-152 }\end{array}$ & - & Feng et al. [139] \\
\hline $\begin{array}{l}\text { Non-alcoholic } \\
\text { steatohepatitis } \\
\text { (NASH) }\end{array}$ & Liver tissue & mice and human & miR-21 & - & Dattaroy et al. [140] \\
\hline & 293T & human & miR-122 & - & Israelow et al. [141] \\
Viral hepatitis C & HepG2 & & & & \\
\hline
\end{tabular}

In recent years, there has been significant interest in investigating the potential for circulatory miRNAs to act as biomarkers of liver disease in adults; however, few studies have been conducted in paediatric liver disease. Those few studies that have examined the potential role of circulating miRNAs in the detection of liver disease have focussed on children with either cystic fibrosis-associated liver disease (CFLD), biliary atresia (BA) or viral hepatitis B.

\subsection{Cystic Fibrosis Liver Disease (CFLD)}

CFLD is a major complication of cystic fibrosis (CF), responsible for up to $5 \%$ of mortality [142]. Sera from children diagnosed with CFLD, cystic fibrosis but no liver disease (CFnoLD) and healthy control children (control) were collected to identify a circulating miRNA signature in CF children (Table 3) [143]. Initially 84 miRNAs were evaluated using a PCR array and validated by qRT-PCR. Analysis revealed upregulation of miR-122 in the CFLD group compared to both CFnoLD and control groups. Of interest this study demonstrated an elevation in serum miR-21 and miR-25 in CFnoLD compared to both CFLD and control groups. Therefore, a panel consisting of miR122, miR-21 and miR-25 showed the potential for early diagnosis of CFLD in clinical settings.

Table 3. Circulatory miRNAs differentially expressed in paediatric liver disease.

\begin{tabular}{|c|c|c|c|c|c|c|}
\hline Disease & $\begin{array}{c}\text { Sample } \\
\text { Type }\end{array}$ & $\begin{array}{l}\text { Sample } \\
\text { Source }\end{array}$ & Method & Upregulated & Downregulated & References \\
\hline $\begin{array}{l}\text { Cystic } \\
\text { fibrosis liver } \\
\text { disease } \\
\text { (CFLD) }\end{array}$ & Serum & Children & $\begin{array}{l}\text { PCR array } \\
\text { qRT-PCR }\end{array}$ & $\begin{array}{c}\text { miR-122 (in CFLD) } \\
\text { miR-21 and } \\
\text { miR-25 (in } \\
\text { CFnoLD) }\end{array}$ & - & Cook et al. [143] \\
\hline \multirow{3}{*}{$\begin{array}{c}\text { Billiary } \\
\text { atresia (BA) }\end{array}$} & Serum & Children & $\begin{array}{l}\text { PCR array } \\
\text { qRT-PCR }\end{array}$ & $\begin{array}{c}\text { miR-200a } \\
\text { miR-200b } \\
\text { miR-429 }\end{array}$ & - & Zahm et al. [144] \\
\hline & Serum & Children & $\begin{array}{l}\text { Microarray } \\
\text { qRT-PCR }\end{array}$ & $\begin{array}{c}\text { miR-92a-3p } \\
\text { miR-4689 } \\
\text { miR-150-3p }\end{array}$ & miR-4429 & Dong et al. [145] \\
\hline & Plasma & Children & $\begin{array}{c}\text { NGS } \\
\text { qRT-PCR }\end{array}$ & $\begin{array}{c}\text { miR-200a-3p } \\
\text { miR-574-5p } \\
\text { miR-194-5p } \\
\text { miR-432-5p } \\
\text { miR-122-5p } \\
\text { miR-100-5p } \\
\text { miR-let7c-5p }\end{array}$ & $\begin{array}{l}\text { miR-10b-5p } \\
\text { miR-140-3p } \\
\text { miR-26a-5p } \\
\text { miR-126-3p } \\
\text { miR-744-5p } \\
\text { miR-370-3p } \\
\text { miR-142-3p } \\
\text { miR-23a-3p }\end{array}$ & Peng et al. [146] \\
\hline
\end{tabular}


Table 3. Cont.

\begin{tabular}{|c|c|c|c|c|c|c|}
\hline Disease & $\begin{array}{c}\text { Sample } \\
\text { Type }\end{array}$ & $\begin{array}{l}\text { Sample } \\
\text { Source }\end{array}$ & Method & Upregulated & Downregulated & References \\
\hline Hepatitis B & Plasma & Children & $\begin{array}{l}\text { PCR array } \\
\text { qRT-PCR }\end{array}$ & $\begin{array}{c}\text { miR-99a-5p } \\
\text { miR-100-5p } \\
\text { miR-122-5p } \\
\text { miR-122-3p } \\
\text { miR-192-5p } \\
\text { miR-192-3p } \\
\text { miR-194-5p } \\
\text { miR-483-3p } \\
\text { miR-855-5p } \\
\text { miR-1247 } \\
\text { miR-28-5p } \\
\text { miR-30a-5p } \\
\text { miR-30e-3p } \\
\text { miR-125b-5p } \\
\text { miR-193b-3p } \\
\text { miR-215 } \\
\text { miR-365a-3p } \\
\text { miR-378a-3p } \\
\text { miR-455-5p } \\
\text { miR-455-3p } \\
\text { miR-574-3p } \\
\text { miR-let-7c }\end{array}$ & miR-654-3p & $\begin{array}{l}\text { Winther et al. [147] } \\
\text { Winther et al. [148] } \\
\text { Winther et al. [149] }\end{array}$ \\
\hline
\end{tabular}

CFLD is believed to arise as a result of impaired function of the cystic fibrosis transmembrane regulator (CFTR) in cholangiocytes, which results in decreased bile flow and blockage of bile ducts. The retention of toxic bile acids [150] within bile ducts and the liver results in hepatocellular injury and activation of hepatic stellate cells (HSC), the principal collagen-producing cell in the liver. This leads to hepatic fibrosis and ultimately, in most, a variable severity of biliary fibrosis progressing to cirrhosis in up to $10 \%$ of children [151]. It is possible that the increased level of serum miR-122 detected in CFLD [143] may be caused by hepatic cell death (Figure 3a), although this requires further investigation. The same study also showed a positive correlation between serum miR-122 and both aspartate amino transferase (AST) and alanine amino transferase (ALT) suggesting a reflection of the liver integrity during disease progression [143].

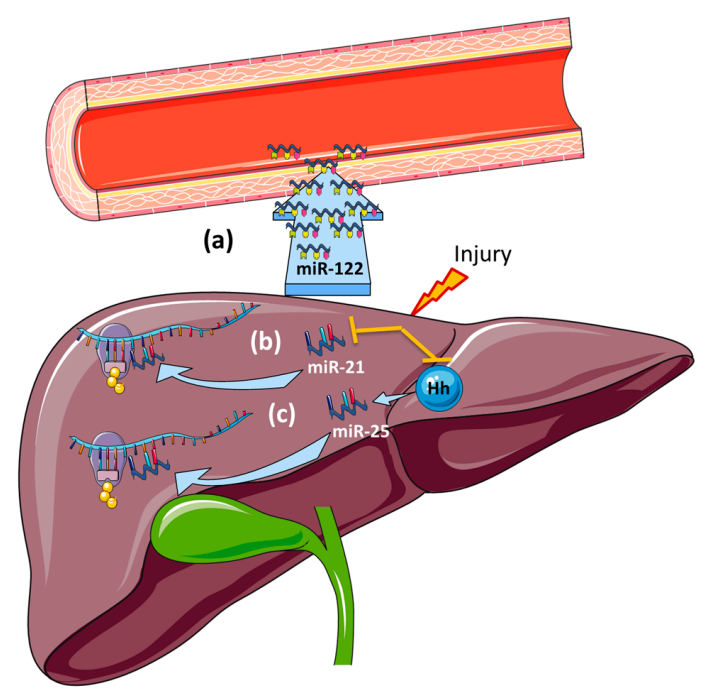

Figure 3. Proposed role of miRNA biomarkers in CFLD. (a) After liver injury, hepatocyte death causes the release of miR-122 into the bloodstream; (b) miRNA-21 has a role in the fibrogenic process by targeting genes involved in cell death and ECM remodeling; (c) Hedgehog (Hh) signalling mediates the expression of miRNA-25 which targets apoptotic genes during liver injury. Hh: Hedgehog signalling. 
miR-21 has been proposed to target genes involved in cell death and extracellular remodelling in different types of cancer including squamous cell carcinoma, as well as both hepatocellular and cholangiocarcinoma [152-154]. Others have shown that the induction of oxidative stress by cytotoxic bile acids reduces the expression of miR-21 in hepatocytes facilitating apoptosis [155]. This suggests that miR-21 may play an important role in liver homeostasis and regeneration [156] (Figure 3b). Moreover, a recent study in non-alcoholic steatohepatitis (NASH) revealed that after oxidative stress, miR-21 elicits fibrogenesis as part of the regeneration process [140].

microRNA- 25 has been implicated in the regulation of apoptosis acting as an anti-apoptotic agent in cholangiocarcinoma [157]. It has been previously shown that activation of Hedgehog signalling, which plays a role in the fibrogenic process are associated with the overexpression of the miR-106b-25 cluster, which miR-25 is part of [158]. DR4, a component of the TRAIL death signalling pathway, is targeted by miR-25 preventing cell apoptosis [157] (Figure 3c). Thus, we propose a hypothetical schema for the possible role of these miRNAs in CFLD and their potential to act as biomarkers in CFLD (see Figure 3). However, further functional studies are required in CFLD to demonstrate a disease specific role for miR-21 and miR-25.

\subsection{Biliary Atresia}

Biliary atresia (BA) is a neonatal liver disease characterized by inflammation and fibrosis of the extrahepatic biliary ducts, leading to cholestasis and biliary cirrhosis [159]. In order to restore bile flow, the only treatment is a Kasai procedure (hepatoportoenterostomy) [159]. However, more than 70\% of patients with a successful Kasai procedure will require a liver transplant during childhood due to ongoing sclerosis of the bile duct [160].

As in the study conducted in CFLD, serum miRNA profiles have been evaluated using PCR arrays in children with BA versus a cholestatic control group including children diagnosed with non-BA cholestatic diseases such as Alagille syndrome or choledocholithiasis (Table 3) [144]. Eleven miRNAs were found to be differentially expressed between the two groups and nine confirmed by qRT-PCR in independent cohorts. miR-200a, miR-200b and miR-429 (members of the miR-200 cluster) were significantly upregulated in BA patients compared to the cholestatic control group. Receiver operating characteristic (ROC) analysis showed the diagnostic utility of miR-200a, miR-200b and miR-429 by correctly diagnosing up to $85 \%$ of patient samples. However, it remains to be demonstrated whether a combination of these microRNAs in a diagnostic panel could improve accuracy.

Similarly, Dong et al. [145] performed a study in 45 BA children and 20 non-BA cholestatic children as controls. Serum from four BA children and four non-BA cholestatic controls was used for the initial microarray analysis identifying 13 differentially expressed miRNAs. Eight miRNAs were selected for validation based on predicted enriched functions and pathways of targeted genes. The validation was performed by qRT-PCR in 10 BA children and 10 non-BA cholestatic controls revealing a decreased expression of miR-4429 and an increased expression of miR-92a-3p, miR-4689 and miR-150-3p in the BA group. In addition, a diagnostic utility analysis was performed by qRT-PCR in 35 BA children and 20 non-BA cholestatic controls. The analysis showed a significant downregulation of miR-4429 and upregulation of miR-4689 in the BA group while the remaining miRNAs were not significantly differentially expressed at this stage. The ROC curve analysis results in an area under the curve (AUC) of 0.789 and 0.722 for miR-4429 and miR-4689, respectively, which according to the authors suggests a promising diagnostic performance. Interestingly, the miRNAs reported by Zhan et al. [144] were not differentially expressed in the Dong et al. study which might be due to small sample size used during the microarray analysis ( $n=4$ /group) or differences in sample cohorts selected. These recurrent differences between reported miRNA expression profiles stress the need for standardized methodological approaches and study designs, including prospective validation in large scale studies.

In BA, fibro-obliteration of the extrahepatic biliary tree results in significantly decreased or absent bile flow, leading to cholangiocyte and hepatocyte injury. Hence, an elevation of serum miR-122 might 
have been expected in BA patients as a marker of liver injury; however, this was not observed in either study. This may be due to the characteristics of the study groups, i.e., the comparator groups in each study were liver disease patients. If compared to a healthy control group, a differential miR-122 expression might have been detected.

In fact, a recent study compared plasma miRNA profiles in children with BA [146] to healthy controls. The study consisted in of an initial "discovery" phase with nine BA patients and nine healthy controls pooled in groups of three. cDNA libraries were constructed from each group and miRNA profiles compared by next-generation sequencing (NGS). From this initial discovery phase, 15 miRNAs were found to be differentially expressed, seven upregulated (miR-200a-3p, miR-574-5p, miR-194-5p. miR-432-5p, miR-122-5p, miR-100-5p and let-7c-5p) and eight downregulated (miR-10b-5p, miR-140-3p, miR-26a-5p, miR-126-3p, miR-744-5p, miR-370-3p, miR-142-3p and miR-23a-3p) in BA patients compared to healthy controls (Table 3). A second phase performed in 44 BA patients, 20 non-BA cholestatic disease patients and 20 healthy controls was used to validate the NGS findings. Based on the high read counts obtained during NGS $(\geq 5000)$ six miRNAs (miR-122-5p, miR-100-sp, miR-140-3p, miR-10b-5p, miR-26a-5p and miR-126-3p) were chosen for validation. The validation phase showed an increase in the levels of miR-122-5p and miR-100-5p and decrease of miR-140-3p and 126-3p in BA patients compared to controls. In addition, BA patients showed a significant decrease of miR-140-3p when compared to cholestatic patients. ROC curve analysis was used to determine the efficacy of miR-140-3p to distinguish BA patients from non-BA patients (controls and other cholestatic disorders) showing a sensitivity and specificity of $66.7 \%$ and $79.1 \%$ respectively. While, decreased miR-140-3p was reported in this study as a potential biomarker to identify BA, there is a lack of clinical accuracy. The inclusion of miR-140-3p as part of an expanded panel of different miRNAs may improve diagnostic utility.

Peng et al. [146] describe an elevated expression of miR-200a which forms part of the miR-200 cluster, confirming the finding previously reported by Zhan et al. [144] in serum samples. As expected, an overexpression of miR-122-5p in plasma from BA patients was found when compared to healthy controls but not when compared to other cholestatic diseases, which suggest that miR-122 is in fact a marker of liver injury. Potential shortcomings of this study include the use of small (pooled) sample size in the NGS discovery phase to identify BA biomarkers. In addition, the decision to choose only miRNAs with read counts over 5000 could have negatively influenced the discovery of a more reliable miRNA diagnostic panel.

Hepatic stellate cells (HSC) play an important role in the liver regeneration process and are responsible for fibrotic tissue synthesis in BA [161]. HSC can be activated by cytokines such as transforming growth factor $\beta$ (TGF- $\beta$ ) [151], which acts as a profibrogenic mediator. miR-200a has been involved in epithelial to mesenchymal transition (EMT) and cell migration mediated by TGF $\beta-1$ signalling in breast cancer [162], and in cardiac [163], renal [164] and pulmonary fibrosis [165]. It is also involved in the inhibition of TGF- $\beta$ by targeting ZEB1 and ZEB2 during renal injuries (Figure 4a) [166,167]. This evidence suggests an anti-fibrotic role for miR-200a in reversing fibrogenic activity [167]. We proposed that the elevation of miR-200a in serum might originate from the destruction of cells during the progression of the disease, which correlates with the decrease of miR-200a observed in BA liver tissue from mice models [127].

As part of the miR-200 cluster, miR-200b and miR-429 have also been associated with EMT during pulmonary fibrosis, intestinal fibrosis and breast cancer $[165,168,169]$. miR-200b has been shown to correlate with liver fibrosis progression in BA patients by targeting FOG2, a known inhibitor of PI3K/Akt signalling [128] which is important for the activation of HSC (Figure 4b). Thus, a role for these miRNAs as BA biomarkers is proposed, with potential mechanism of action in BA liver depicted in Figure 4. However, once again, further mechanistic studies are required to validate these possible pathways of miRNA regulation of hepatic fibrogenesis in BA. 


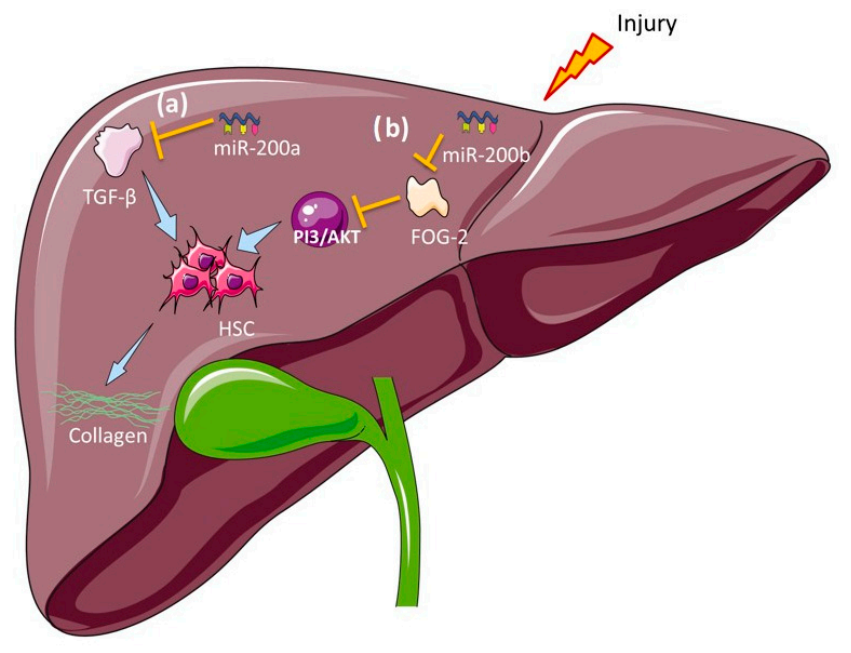

Figure 4. Proposed role of miRNA biomarkers in BA. (a) miRNA-200a is involved in the inhibition of TGF- $\beta$ induced HSC activation and collagen synthesis, suggesting an anti-fibrotic role; (b) miRNA-200b enhances the PI3K/Akt signalling by targeting FOG2, which activates HSCs and collagen synthesis. TGF- $\beta$ : transforming growth factor $\beta$; HSC: hepatic stellate cells; FOG2: friend of GATA protein 2.

\subsection{Viral Hepatitis $B$}

Chronic hepatitis $\mathrm{B}(\mathrm{CHB})$ is a global health burden that according to the World Health Organization (WHO) affects an estimated 240 million people worldwide [170]. Children can be infected during birth or at early infancy, with infections persisting in $90 \%$ of cases and around $5 \%$ developing chronic disease [171]. CHB is defined as positive for surface antigen of hepatitis B virus (HBsAg) for over six months. Liver damage in viral hepatitis is caused by immune responses to cells infected with the virus which over the course of $\mathrm{CHB}$ presents three characteristic stages: immune-tolerant, immune-active and immune-inactive [172]. Immunological phases are primarily characterised by the persistence of hepatitis Be antigen (HBeAg), high levels of hepatitis B virus and ALT. Children in the immune inactive stage have a lower risk of liver disease progression, however, hepatitis $B$ virus reactivation may occur [173]. Winther et al. compared plasma miRNA levels in children with HBeAg+ and HBeAg - versus healthy controls (Table 3) [147]. Differentially expressed miRNAs were assessed by PCR arrays, identifying the upregulation of 16 miRNAs (miRNA-99a, miRNA-100, miRNA-122-5p, miRNA-122-3p, miRNA-125b, miRNA-192-5p, miRNA-192-3p, miRNA-193b, miRNA-194, miRNA-215, miRNA-356, miRNA-455-5p, miRNA-455-3p, miRNA-483-3p, miRNA-885-5p and miRNA-1247) for which expression was highest in the HBeAg+ group, lower in HBeAg - group and lowest in the healthy control group. A gene set enrichment analysis showed these miRNAs are involved in insulin, MAPK or WNT signalling pathways.

A follow up study (Table 3) [148] focused on the association of these 16 miRNAs with HBsAg over the course of CHB. Children were classified according to their immunological phase as immune-tolerant, immune-active and immune-inactive. While miR-455-3p and miR-1247-5p were not assessed due to technical issues, the remaining 14 miRNAs were all highly expressed in the immune-tolerant group, lower in immune-active group and lowest in immune-inactive group. Interestingly, levels of expression of HBsAg followed the same pattern among the three groups, showing a strong correlation between plasma miRNA levels, HBsAg and HBV DNA.

In a more recent study, Winther et al. identified liver specific target genes in plasma of HBeAg+ children (Table 3) [149]. Using the raw data from the original study [147], plasma miRNA expression was re-analyzed from $\mathrm{HBeAg}+, \mathrm{HBeAg}-$ and the healthy control groups. Thirty-two miRNAs were shown to be significantly differentially expressed between $\mathrm{HBeAg}+$ and $\mathrm{HBeAg}-$ children. In addition to the 14 miRNAs described in the previous studies $[147,148]$, nine upregulated and nine downregulated miRNAs were identified. 
Identification of liver specific miRNA targets of the 32 miRNAs was performed using CLIP-seq overlap. Out of these 32 miRNAs, 16 miRNAs were found to be liver specific. Furthermore, these 16 miRNAs were found to target 16 genes, with each miRNA targeting multiple genes. The identified target genes were: ACADSB, ARIDIA, BTG3, CEBP6, CPOX, E2F1, FRAT2, GABBR1, GATA6, HOXA9, LEF1, MAZ, PAPD5, SF1, SMAD4 and ZXDB.

From the 16 miRNAs analysed, six were previously validated $[147,148]$, the remaining were validated by qRT-PCR. Validation confirmed miR-28-5p, miR-30a-5p, miR-30e-3p, miR-378a-3p, miR-574-3p and let-7c to be upregulated and miR-654-3p to be downregulated in HBeAg+ compared to HBeAg - groups. Comparing the HBeAg - and healthy control groups, only miR-28-5p and miR-30a-5p were upregulated, whereas miR-654-3p showed no statistically significant difference.

These results suggest a correlation between the miRNAs described above, HBV DNA and HBeAg, thus implying a role in viral replication. The role of the aforementioned miRNAs during the progression of $\mathrm{CHB}$ was clear by studying their relationship with the different immunological phases. Winther et al. proposed that over time immunological control is possible with plasma miRNA levels as they inversely correlated to immunological control. This suggests that a panel of miRNAs could be used to identify the immunological status of patients. From the above identified miRNA target genes the majority have been described as regulators or suppressors of carcinogenesis or HBV replication [174-178]. This, once more, highlights the role of microRNA during the course of infection and liver damage; however, further studies are required to clarify the mechanisms involved.

Interestingly, some of the differentially expressed plasma miRNAs found by Winther et al. have also been reported in circulatory miRNA profiling in an adult population. Brunetto et al. [65] showed overexpression of serum miR-122-5p, miR-99a-5p and miR-192-5p between inactive HBsAg carriers and $\mathrm{CHB}$ patients. Furthermore, this miRNA expression was correlated to the levels of circulatory HBsAg particles. These observations in adults are consistent with the one reported by Winther et al. [148] comparing levels of plasma miRNAs in children with CHB considering HBsAg levels. Likewise, Ninomiya et al. [179] reported upregulation of serum miR-100-5p, miR-125b-5p, miR-193b-3p, miR-194-3p, miR-30a-3p, miR-30c-2-3p, miR-3591-5p, miR-4709-3p, miR-574-3p and miR-99a-5p of CHB adult patients compared to healthy controls. Overall, seven of these miRNAs including miR-99a, miR-100-5p, miR-194, miR-30a, miR-125b and miR-574, are consistently reported to be upregulated in CHB in both serum from adults [179] and plasma from children [147,148].

\section{Conclusions}

The true prevalence and morbidity of paediatric chronic liver disease is unknown, however, every year thousands of children are hospitalized for liver diseases of varying aetiologies. Ultimately, these diseases have a direct impact on quality of life, with significant associated costs to the health care system. In addition, these paediatric conditions are a precursor of chronic liver pathologies in adult life [180].

There is a clear need for reliable, non-invasive methods to identify liver disease at an early age, especially where timely intervention is critical for improved patient outcomes. Our understanding of miRNAs and their role in different liver pathologies is increasing rapidly. During the past two decades, 2588 mature miRNAs have been described in humans [69], miRNA mechanisms of translational repression [181] and target identification [182] have also been widely studied. Yet, microRNA involvement in liver disease, especially in paediatrics, needs further investigation and elucidation.

A key feature of miRNAs is their stability in serum and plasma due to their association with Ago2 [183], exosomes [93], apoptotic bodies [184] or HDL [185]. This robust stability, together with demonstrated organ- and disease-specific expression, enable miRNAs to act as potential non-invasive biomarkers for the detection and diagnosis of liver disease, and the assessment of hepatic fibrotic stage providing the ability to monitor the development of cirrhosis. Over the past ten years numerous studies, mostly conducted in animal models or in human tissue samples, have demonstrated a disease-specific link between specific miRNAs and chronic liver disease. The increasing literature exploring the role of 
miRNAs in liver has expanded our knowledge about the mechanisms that drive physiological and pathological hepatic functions. It is now known that miR-122 accounts for over half of the miRNAs expressed in liver followed by miR-192 and miR-199a/b-3p (52\%, 17\% and 5\%, respectively) [186]. Along with this increased knowledge of hepatic miRNA function, there has been a natural exploration of their potential to act as both circulating biomarkers of disease status and indeed as novel therapeutics. However, a significant majority of these studies have been performed in adult chronic liver disease (reviewed elsewhere [55]), especially in the assessment of circulatory miRNA signatures. Considering the multiple pathologies causing paediatric liver disease, only cystic fibrosis associated liver disease, biliary atresia and chronic hepatitis B, have been studied to determine the utility of circulatory miRNAs as biomarkers of hepatic disease. Further paediatric studies are needed especially in children with NAFLD, as with an estimated prevalence of $7.6 \%$ in the general population and $34.2 \%$ in obese children [187], NAFLD is currently the most common cause of paediatric liver disease [188]. Indeed, there are a large number of additional paediatric liver diseases that may benefit from the use of miRNAs as biomarkers for differential diagnosis, determining prognosis and potentially to elucidate disease mechanism, including such conditions as Crigler-Najjar syndrome, Gilbert syndrome, Wilson disease, hepatoblastoma, angiosarcoma, infantile hepatic haemangioma, allagile syndrome, A-1 antitrypsin disorder and autoimmune hepatitis.

In order to complete the translation of these studies into the clinical setting, some challenges need to be addressed. The establishment of standardized methodological design for low yield isolation from biologic fluids, accurate quantification and normalization will greatly benefit reproducibility and translation into the clinic. As our understanding of miRNAs increases, new opportunities will arise in their use not only as diagnostic tools but also as potential therapeutic treatments for both paediatric chronic liver disease and liver cancer.

Acknowledgments: Diego A. Calvopina is sponsored by The Australian Liver Foundation (ALF) Pitcher Partners PhD Scholarship for Paediatric Liver Disease Research. This work was supported by funding from the National Health and Medical Research Council (NHMRC) of Australia (APP1048740). Grant A. Ramm is support by a NHMRC Senior Research Fellowship (APP1061332).

Author Contributions: Diego A. Calvopina researched the content, wrote the manuscript and designed tables and figures. Miranda A. Coleman, Peter J. Lewindon and Grant A. Ramm edited, revised and approved the final version of the review.

Conflicts of Interest: The authors declare no conflict of interest.

\section{Abbreviations}

$\begin{array}{ll}\text { A } & \text { Adenine } \\ \text { AGO } & \text { Argonaute } \\ \text { ALD } & \text { Alcoholic liver disease } \\ \text { ALF } & \text { Acute liver failure } \\ \text { ALT } & \text { Alanine amino transferase } \\ \text { AST } & \text { Aspartate amino transferase } \\ \text { AUC } & \text { Area under the curve } \\ \text { BA } & \text { Biliary atresia } \\ \text { CF } & \text { Cystic fibrosis } \\ \text { CFLD } & \text { Cystic fibrosis-associated liver disease } \\ \text { CFnoLD } & \text { Cystic fibrosis no liver disease } \\ \text { CFTR } & \text { Cystic fibrosis transmembrane regulator } \\ \text { CHB } & \text { Chronic hepatitis B } \\ \text { eIF4 } & \text { Eukaryotic translation-initiation factor 4 } \\ \text { EMT } & \text { Epithelial to mesenchymal transition } \\ \text { ESCRT } & \text { Endosomal sorting complex required for transport } \\ \text { EV } & \text { Extracellular vesicle } \\ \text { HBeAg } & \text { Hepatitis Be antigen } \\ \text { HBsAg } & \text { Surface antigen of hepatitis B virus } \\ \text { HDL } & \text { High-density lipoprotein } \\ \text { Hh } & \text { Hedgehog } \\ \text { hnRNPA2B1 } & \text { Heterogeneous nuclear ribonucleoprotein A2B1 } \\ \text { HSC } & \text { Hepatic stellate cells }\end{array}$




$\begin{array}{ll}\text { IRES } & \text { Internal ribosome entry site } \\ \text { miR } & \text { microRNA } \\ \text { miRNA } & \text { microRNA } \\ \text { mRNA } & \text { Messenger RNA } \\ \text { mRNP } & \text { Messenger ribonucleoprotein } \\ \text { MVE } & \text { Multivesicular endosomes } \\ \text { NAFLD } & \text { Non-alcoholic fatty liver disease } \\ \text { NASH } & \text { Non-alcoholic steatohepatitis } \\ \text { NGS } & \text { Next-generation sequencing } \\ \text { nt } & \text { Nucleotide } \\ \text { PABP } & \text { Poly(A) binding protein } \\ \text { pre-miRNAs } & \text { Precursor miRNAs } \\ \text { pri-miRNAs } & \text { Primary miRNAs } \\ \text { RISC } & \text { RNA-induced silencing complex } \\ \text { RNases } & \text { Ribonucleases } \\ \text { ROC } & \text { Receiver operating characteristic } \\ \text { SNP } & \text { Single nucleotide polymorphism } \\ \text { TGF- } \beta & \text { Transforming growth factor } \beta \\ \text { WHO } & \text { World Health Organization }\end{array}$

\section{References}

1. Arya, G.; Balistreri, W.F. Pediatric liver disease in the United States: Epidemiology and impact. J. Gastroenterol. Hepatol. 2002, 17, 521-525. [CrossRef] [PubMed]

2. Chang, J.; Nicolas, E.; Marks, D.; Sander, C.; Lerro, A.; Buendia, M.A.; Xu, C.; Mason, W.S.; Moloshok, T.; Bort, R. miR-122, a mammalian liver-specific microRNA, is processed from hcr mRNA and may downregulate the high affinity cationic amino acid transporter CAT-1. RNA Biol. 2004, 1, 106-113. [CrossRef] [PubMed]

3. Lee, R.C.; Feinbaum, R.L.; Ambros, V. The C. elegans heterochronic gene lin-4 encodes small RNAs with antisense complementarity to lin-14. Cell 1993, 75, 843-854. [CrossRef]

4. Reinhart, B.J.; Slack, F.J.; Basson, M.; Pasquinelli, A.E.; Bettinger, J.C.; Rougvie, A.E.; Horvitz, H.R.; Ruvkun, G. The 21-nucleotide let-7 RNA regulates developmental timing in Caenorhabditis elegans. Nature 2000, 403, 901-906. [PubMed]

5. Pasquinelli, A.E.; Reinhart, B.J.; Slack, F.; Martindale, M.Q.; Kuroda, M.I.; Maller, B.; Hayward, D.C.; Ball, E.E.; Degnan, B.; Muller, P.; et al. Conservation of the sequence and temporal expression of let-7 heterochronic regulatory RNA. Nature 2000, 408, 86-89. [PubMed]

6. Lee, R.C.; Ambros, V. An extensive class of small RNAs in Caenorhabditis elegans. Science 2001, $294,862-864$. [CrossRef] [PubMed]

7. Lau, N.C.; Lim, L.P.; Weinstein, E.G.; Bartel, D.P. An abundant class of tiny RNAs with probable regulatory roles in Caenorhabditis elegans. Science 2001, 294, 858-862. [CrossRef] [PubMed]

8. Lagos-Quintana, M.; Rauhut, R.; Lendeckel, W.; Tuschl, T. Identification of novel genes coding for small expressed RNAs. Science 2001, 294, 853-858. [CrossRef] [PubMed]

9. Bartel, D.P. Micrornas: Genomics, biogenesis, mechanism, and function. Cell 2004, 116, 281-297. [CrossRef]

10. Cai, X.; Hagedorn, C.H.; Cullen, B.R. Human microRNAs are processed from capped, polyadenylated transcripts that can also function as mRNAs. RNA 2004, 10, 1957-1966. [CrossRef] [PubMed]

11. Lee, Y.; Kim, M.; Han, J.; Yeom, K.H.; Lee, S.; Baek, S.H.; Kim, V.N. MicroRNA genes are transcribed by RNA polymerase II. EMBO J. 2004, 23, 4051-4060. [CrossRef] [PubMed]

12. Lee, Y.; Jeon, K.; Lee, J.T.; Kim, S.; Kim, V.N. MicroRNA maturation: Stepwise processing and subcellular localization. EMBO J. 2002, 21, 4663-4670. [CrossRef] [PubMed]

13. Ruby, J.G.; Jan, C.H.; Bartel, D.P. Intronic microRNA precursors that bypass Drosha processing. Nature 2007, 448, 83-86. [CrossRef] [PubMed]

14. Sun, G.; Yan, J.; Noltner, K.; Feng, J.; Li, H.; Sarkis, D.A.; Sommer, S.S.; Rossi, J.J. Snps in human miRNA genes affect biogenesis and function. RNA 2009, 15, 1640-1651. [CrossRef] [PubMed]

15. Han, J.; Lee, Y.; Yeom, K.-H.; Kim, Y.-K.; Jin, H.; Kim, V.N. The DROSHA-DGCR8 complex in primary microRNA processing. Genes Dev. 2004, 18, 3016-3027. [CrossRef] [PubMed]

16. Hannon, G.J.; Plasterk, R.H.A.; Denli, A.M.; Tops, B.B.J.; Ketting, R.F. Processing of primary microRNAs by the microprocessor complex. Nature 2004, 432, 231-235. 
17. Lee, Y.; Ahn, C.; Han, J.; Choi, H.; Kim, J.; Yim, J.; Lee, J.; Provost, P.; Radmark, O.; Kim, S. The nuclear RNAse III Drosha initiates microRNA processing. Nature 2003, 425, 415-419. [CrossRef] [PubMed]

18. Lund, E.; Güttinger, S.; Calado, A.; Dahlberg, J.E.; Kutay, U. Nuclear export of microRNA precursors. Science 2004, 303, 95-98. [CrossRef] [PubMed]

19. Bohnsack, M.T.; Czaplinski, K.; Gorlich, D. Exportin 5 is a RanGTP-dependent dsRNA-binding protein that mediates nuclear export of pre-miRNAs. RNA 2004, 10, 185-191. [CrossRef] [PubMed]

20. Caudy, A.A.; Bernstein, E.; Hannon, G.J.; Hammond, S.M. Role for a bidentate ribonuclease in the initiation step of RNA interference. Nature 2001, 409, 363-366.

21. Hutvágner, G.; McLachlan, J.; Pasquinelli, A.E.; Bálint, É.; Tuschl, T.; Zamore, P.D. A cellular function for the RNA-interference enzyme Dicer in the maturation of the let-7 small temporal RNA. Science 2001, 293, 834-838. [CrossRef] [PubMed]

22. Grishok, A.; Pasquinelli, A.E.; Conte, D.; Li, N.; Parrish, S.; Ha, I.; Baillie, D.L.; Fire, A.; Ruvkun, G.; Mello, C.C. Genes and mechanisms related to RNA interference regulate expression of the small temporal RNAs that control C. elegans developmental timing. Cell 2001, 106, 23-34. [CrossRef]

23. Ketting, R.F.; Fischer, S.E.; Bernstein, E.; Sijen, T.; Hannon, G.J.; Plasterk, R.H. Dicer functions in RNA interference and in synthesis of small RNA involved in developmental timing in C. elegans. Genes Dev. 2001, 15, 2654-2659. [CrossRef] [PubMed]

24. Chen, P.Y.; Meister, G. MicroRNA-guided posttranscriptional gene regulation. Biol. Chem. 2005, 386, 1205-1218. [CrossRef] [PubMed]

25. Beach, D.; Bernstein, E.; Hammond, S.M.; Hannon, G.J. An RNA-directed nuclease mediates post-transcriptional gene silencing in Drosophila cells. Nature 2000, 404, 293-296.

26. Mourelatos, Z.; Dostie, J.; Paushkin, S.; Sharma, A.; Charroux, B.; Abel, L.; Rappsilber, J.; Mann, M.; Dreyfuss, G. Mirnps: A novel class of ribonucleoproteins containing numerous microRNAs. Genes Dev. 2002, 16, 720-728. [CrossRef] [PubMed]

27. Schirle, N.T.; MacRae, I.J. The crystal structure of human Argonaute2. Science 2012, 336, 1037-1040. [CrossRef] [PubMed]

28. Simon, B.; Lingel, A.; Izaurralde, E.; Sattler, M. Structure and nucleic-acid binding of the Drosophila Argonaute 2 PAZ domain. Nature 2003, 426, 465-469.

29. Kawamata, T.; Tomari, Y. Making RISC. Trends Biochem. Sci. 2010, 35, 368-376. [CrossRef] [PubMed]

30. Förstemann, K.; Horwich, M.D.; Wee, L.; Tomari, Y.; Zamore, P.D. Drosophila microRNAs are sorted into functionally distinct Argonaute complexes after production by Dicer-1. Cell 2007, 130, 287-297. [CrossRef] [PubMed]

31. Iwasaki, S.; Paroo, Z.; Liu, Q.; Ye, X.; Tomari, Y.; Kawamata, T.; Yoda, M. ATP-dependent human RISC assembly pathways. Nat. Struct. Mol. Biol. 2010, 17, 17-23.

32. Meister, G.; Landthaler, M.; Patkaniowska, A.; Dorsett, Y.; Teng, G.; Tuschl, T. Human Argonaute2 mediates RNA cleavage targeted by miRNAs and siRNAs. Mol. Cell 2004, 15, 185-197. [CrossRef] [PubMed]

33. Song, J.-J.; Smith, S.K.; Hannon, G.J.; Joshua-Tor, L. Crystal structure of Argonaute and its implications for RISC slicer activity. Science 2004, 305, 1434-1437. [CrossRef] [PubMed]

34. Tomari, Y.; Kawamata, T.; Seitz, H. Structural determinants of miRNAs for RISC loading and slicer-independent unwinding. Nat. Struct. Mol. Biol. 2009, 16, 953-960.

35. Kühn, U.; Wahle, E. Structure and function of poly(A) binding proteins. Biochim. Biophys. Acta 2004, $1678,67$. [CrossRef] [PubMed]

36. Mangus, D.; Evans, M.; Jacobson, A. Poly(A)-binding proteins: Multifunctional scaffolds for the post-transcriptional control of gene expression. Genome Biol. 2003, 4, 223. [CrossRef] [PubMed]

37. Meister, G. miRNAs get an early start on translational silencing. Cell 2007, 131, 25-28. [CrossRef] [PubMed]

38. Petersen, C.P.; Bordeleau, M.-E.; Pelletier, J.; Sharp, P.A. Short RNAs repress translation after initiation in mammalian cells. Mol. Cell 2006, 21, 533-542. [CrossRef] [PubMed]

39. Pillai, R.S.; Bhattacharyya, S.N.; Artus, C.G.; Zoller, T.; Cougot, N.; Basyuk, E.; Bertrand, E.; Filipowicz, W. Inhibition of translational initiation by let-7 microRNA in human cells. Science 2005, 309, 1573-1576. [CrossRef] [PubMed]

40. Piao, X.; Zhang, X.; Wu, L.; Belasco, J.G. Ccr4-Not deadenylates mRNA associated with RNA-induced silencing complexes in human cells. Mol. Cell. Biol. 2010, 30, 1486-1494. [CrossRef] [PubMed] 
41. Braun, J.E.; Huntzinger, E.; Fauser, M.; Izaurralde, E. Gw182 proteins directly recruit cytoplasmic deadenylase complexes to miRNA targets. Mol. Cell 2011, 44, 120-133. [CrossRef] [PubMed]

42. Chekulaeva, M.; Mathys, H.; Zipprich, J.T.; Attig, J.; Colic, M.; Parker, R.; Filipowicz, W. MiRNA repression involves Gw182-mediated recruitment of Ccr4-Not through conserved W-containing motifs. Nat. Struct. Mol. Biol. 2011, 18, 1218-1226. [CrossRef] [PubMed]

43. Behm-Ansmant, I.; Rehwinkel, J.; Doerks, T.; Stark, A.; Bork, P.; Izaurralde, E. mRNA degradation by miRNAs and Gw182 requires both Ccr4: Not deadenylase and Dcp1: Dcp2 decapping complexes. Genes Dev. 2006, 20, 1885-1898. [CrossRef] [PubMed]

44. Bagga, S.; Bracht, J.; Hunter, S.; Massirer, K.; Holtz, J.; Eachus, R.; Pasquinelli, A.E. Regulation by let-7 and lin-4 miRNAs results in target mRNA degradation. Cell 2005, 122, 553-563. [CrossRef] [PubMed]

45. Valencia-Sanchez, M.A.; Liu, J.; Hannon, G.J.; Parker, R. Control of translation and mRNA gradation by miRNAs and siRNAs. Genes Dev. 2006, 20, 515-524. [CrossRef] [PubMed]

46. Thermann, R.; Hentze, M.W. Drosophila miR2 induces pseudo-polysomes and inhibits translation initiation. Nature 2007, 447, 875-878. [CrossRef] [PubMed]

47. Parker, R.; Sheth, U. P bodies and the control of mRNA translation and degradation. Mol. Cell 2007, 25, 635-646. [CrossRef] [PubMed]

48. Valencia-Sanchez, M.A.; Hannon, G.J.; Liu, J.; Parker, R. MicroRNA-dependent localization of targeted mRNAs to mammalian p-bodies. Nat. Cell Biol. 2005, 7, 719-723.

49. Simard, M.J.; Nottrott, S.; Richter, J.D. Human let-7a miRNA blocks protein production on actively translating polyribosomes. Nat. Struct. Mol. Biol. 2006, 13, 1108-1114.

50. Brennecke, J.; Stark, A.; Russell, R.B.; Cohen, S.M. Principles of microRNA-target recognition. PLoS Biol. 2005, 3, e85. [CrossRef] [PubMed]

51. Krek, A.; Grün, D.; Poy, M.N.; Wolf, R.; Rosenberg, L.; Epstein, E.J.; MacMenamin, P.; da Piedade, I.; Gunsalus, K.C.; Stoffel, M. Combinatorial microRNA target predictions. Nat. Genet. 2005, 37, 495-500. [CrossRef] [PubMed]

52. Lewis, B.P.; Shih, I.H.; Jones-Rhoades, M.W.; Bartel, D.P.; Burge, C.B. Prediction of mammalian microRNA targets. Cell 2003, 115, 787-798. [CrossRef]

53. Lewis, B.P.; Burge, C.B.; Bartel, D.P. Conserved seed pairing, often flanked by adenosines, indicates that thousands of human genes are microRNA targets. Cell 2005, 120, 15-20. [CrossRef] [PubMed]

54. Grimson, A.; Farh, K.K.-H.; Johnston, W.K.; Garrett-Engele, P.; Lim, L.P.; Bartel, D.P. MicroRNA targeting specificity in mammals: Determinants beyond seed pairing. Mol. Cell 2007, 27, 91-105. [CrossRef] [PubMed]

55. Szabo, G.; Bala, S. MicroRNAs in liver disease. Nat. Rev. Gastroenterol. Hepatol. 2013, 10, 542-552. [CrossRef] [PubMed]

56. Bala, S.; Petrasek, J.; Mundkur, S.; Catalano, D.; Levin, I.; Ward, J.; Alao, H.; Kodys, K.; Szabo, G. Circulating microRNAs in exosomes indicate hepatocyte injury and inflammation in alcoholic, drug-induced, and inflammatory liver diseases. Hepatology 2012, 56, 1946-1957. [CrossRef] [PubMed]

57. Zhang, Y.; Jia, Y.; Zheng, R.; Guo, Y.; Wang, Y.; Guo, H.; Fei, M.; Sun, S. Plasma microRNA-122 as a biomarker for viral-, alcohol-, and chemical-related hepatic diseases. Clin. Chem. 2010, 56, 1830-1838. [CrossRef] [PubMed]

58. Cermelli, S.; Ruggieri, A.; Marrero, J.A.; Ioannou, G.N.; Beretta, L. Circulating microRNAs in patients with chronic hepatitis C and non-alcoholic fatty liver disease. PLoS ONE 2011, 6, e23937. [CrossRef] [PubMed]

59. Salvoza, N.C.; Klinzing, D.C.; Gopez-Cervantes, J.; Baclig, M.O. Association of circulating serum miR-34a and miR-122 with dyslipidemia among patients with non-alcoholic fatty liver disease. PLoS ONE 2016, 11, e0153497. [CrossRef] [PubMed]

60. Afonso, M.B.; Rodrigues, P.M.; Simao, A.L.; Castro, R.E. Circulating microRNAs as potential biomarkers in non-alcoholic fatty liver disease and hepatocellular carcinoma. J. Clin. Med. 2016, 5, 30. [CrossRef] [PubMed]

61. Becker, P.P.; Rau, M.; Schmitt, J.; Malsch, C.; Hammer, C.; Bantel, H.; Mullhaupt, B.; Geier, A. Performance of serum microRNAs -122, -192 and -21 as biomarkers in patients with non-alcoholic steatohepatitis. PLoS ONE 2015, 10, e0142661. [CrossRef] [PubMed]

62. Bala, S.; Tilahun, Y.; Taha, O.; Alao, H.; Kodys, K.; Catalano, D.; Szabo, G. Increased microRNA-155 expression in the serum and peripheral monocytes in chronic HCV infection. J. Transl. Med. 2012, 10, 151. [CrossRef] [PubMed] 
63. Polyak, S.J. The circulatory orbit of micro-RNAs in hepatitis C. Hepatology 2013, 58, 847-849. [CrossRef] [PubMed]

64. Ji, F.; Yang, B.; Peng, X.; Ding, H.; You, H.; Tien, P. Circulating microRNAs in hepatitis B virus-infected patients. J. Viral Hepat. 2011, 18, e242-e251. [CrossRef] [PubMed]

65. Brunetto, M.R.; Cavallone, D.; Oliveri, F.; Moriconi, F.; Colombatto, P.; Coco, B.; Ciccorossi, P.; Rastelli, C.; Romagnoli, V.; Cherubini, B. A serum microRNA signature is associated with the immune control of chronic hepatitis B virus infection. PLoS ONE 2014, 9, e110782. [CrossRef] [PubMed]

66. Starkey Lewis, P.J.; Dear, J.; Platt, V.; Simpson, K.J.; Craig, D.G.; Antoine, D.J.; French, N.S.; Dhaun, N.; Webb, D.J.; Costello, E.M.; et al. Circulating microRNAs as potential markers of human drug-induced liver injury. Hepatology 2011, 54, 1767-1776. [CrossRef] [PubMed]

67. Baek, D.; Villén, J.; Shin, C.; Camargo, F.D.; Gygi, S.P.; Bartel, D.P. The impact of microRNAs on protein output. Nature 2008, 455, 64-71. [CrossRef] [PubMed]

68. Friedman, R.C.; Farh, K.K.; Burge, C.B.; Bartel, D.P. Most mammalian mRNAs are conserved targets of microRNAs. Genome Res. 2009, 19, 92-105. [CrossRef] [PubMed]

69. Mirbase. Available online: http://www.mirbase.org/cgi-bin/browse.pl?org=hsa (accessed on 18 August 2016).

70. Aherne, S.T.; Madden, S.F.; Hughes, D.J.; Pardini, B.; Naccarati, A.; Levy, M.; Vodicka, P.; Neary, P.; Dowling, P.; Clynes, M. Circulating miRNAs miR-34a and miR-150 associated with colorectal cancer progression. BMC Cancer 2015. [CrossRef] [PubMed]

71. Salazar, C.; Calvopiña, D.; Punyadeera, C. miRNAs in human papilloma virus associated oral and oropharyngeal squamous cell carcinomas. Expert Rev. Mol. Diagn. 2014, 14, 1033-1040. [CrossRef] [PubMed]

72. Sinha, S.K.; Sattar, A. A robust approach to identifying differential circulating miRNAs in breast cancer. Int. J. Stat. Probab. 2014, 4. [CrossRef]

73. Shen, J.; Wang, A.; Wang, Q.; Gurvich, I.; Siegel, A.B.; Remotti, H.; Santella, R.M. Exploration of genome-wide circulating microRNA in hepatocellular carcinoma: miR-483-5p as a potential biomarker. Cancer Epidemiol. Biomark. Prev. 2013, 22, 2364-2373. [CrossRef] [PubMed]

74. Miller, C.L.; Haas, U.; Diaz, R.; Leeper, N.J.; Kundu, R.K.; Patlolla, B.; Assimes, T.L.; Kaiser, F.J.; Perisic, L.; Hedin, U.; et al. Coronary heart disease-associated variation in TCF21 disrupts a miR-224 binding site and miRNA-mediated regulation. PLoS Genet. 2014, 10, e1004263. [CrossRef] [PubMed]

75. Ren, J.; Zhang, J.; Xu, N.; Han, G.; Geng, Q.; Song, J.; Li, S.; Zhao, J.; Chen, H. Signature of circulating microRNAs as potential biomarkers in vulnerable coronary artery disease. PLoS ONE 2013, 8, e80738. [CrossRef] [PubMed]

76. Wang, F.; Long, G.; Zhao, C.; Li, H.; Chaugai, S.; Wang, Y.; Chen, C.; Wang, D.W. Atherosclerosis-related circulating miRNAs as novel and sensitive predictors for acute myocardial infarction. PLoS ONE 2014, 9 , e105734. [CrossRef] [PubMed]

77. Fenoglio, C.; Ridolfi, E.; Cantoni, C.; de Riz, M.; Bonsi, R.; Serpente, M.; Villa, C.; Pietroboni, A.M.; Naismith, R.T.; Alvarez, E.; et al. Decreased circulating miRNA levels in patients with primary progressive multiple sclerosis. Mult. Scler. J. 2013, 19, 1938-1942. [CrossRef] [PubMed]

78. Punga, T.; Panse, R.; Andersson, M.; Truffault, F.; Berrih-Aknin, S.; Punga, A.R. Circulating miRNAs in myasthenia gravis: miR-150-5p as a new potential biomarker. Ann. Clin. Transl. Neurol. 2014, 1, 49-58. [CrossRef] [PubMed]

79. Zeng, L.; Cui, J.; Wu, H.; Lu, Q. The emerging role of circulating microRNAs as biomarkers in autoimmune diseases. Autoimmunity 2014, 47, 419-429. [CrossRef] [PubMed]

80. Arataki, K.; Hayes, C.N.; Akamatsu, S.; Akiyama, R.; Abe, H.; Tsuge, M.; Miki, D.; Ochi, H.; Hiraga, N.; Imamura, M.; et al. Circulating microRNA-22 correlates with microRNA-122 and represents viral replication and liver injury in patients with chronic hepatitis B. J. Med. Virol. 2013, 85, 789-798. [CrossRef] [PubMed]

81. El-Diwany, R.; Wasilewski, L.N.; Witwer, K.W.; Bailey, J.R.; Page, K.; Ray, S.C.; Cox, A.L.; Thomas, D.L.; Balagopal, A. Acute hepatitis $C$ virus infection induces consistent changes in circulating microRNAs that are associated with nonlytic hepatocyte release. J. Virol. 2015, 89, 9454. [CrossRef] [PubMed]

82. Shrivastava, S.; Petrone, J.; Steele, R.; Lauer, G.M.; Bisceglie, A.M.; Ray, R.B. Up-regulation of circulating miR-20a is correlated with hepatitis C virus-mediated liver disease progression. Hepatology 2013, 58, 863-871. [CrossRef] [PubMed] 
83. Sinigaglia, A.; Lavezzo, E.; Trevisan, M.; Sanavia, T.; Di Camillo, B.; Peta, E.; Scarpa, M.; Castagliuolo, I.; Guido, M.; Sarcognato, S.; et al. Changes in microRNA expression during disease progression in patients with chronic viral hepatitis. Liver Int. 2015, 35, 1324-1333. [CrossRef] [PubMed]

84. Ben-Dov, I.Z.; Tan, Y.-C.; Morozov, P.; Wilson, P.D.; Rennert, H.; Blumenfeld, J.D.; Tuschl, T. Urine microRNA as potential biomarkers of autosomal dominant polycystic kidney disease progression: Description of miRNA profiles at baseline. PLoS ONE 2014, 9, e86856. [CrossRef] [PubMed]

85. Burgos, K.L.; Javaherian, A.; Bomprezzi, R.; Ghaffari, L.; Rhodes, S.; Courtright, A.; Tembe, W.; Kim, S.; Metpally, R.; van Keuren-Jensen, K. Identification of extracellular miRNA in human cerebrospinal fluid by next-generation sequencing. RNA 2013, 19, 712-722. [CrossRef] [PubMed]

86. Liu, T.E.; Cheng, W.; Gao, Y.; Wang, H.U.I.; Liu, Z. Microarray analysis of microRNA expression patterns in the semen of infertile men with semen abnormalities. Mol. Med. Rep. 2012, 6, 535-542. [CrossRef] [PubMed]

87. Salazar, C.; Nagadia, R.; Pandit, P.; Cooper-White, J.; Banerjee, N.; Dimitrova, N.; Coman, W.B.; Punyadeera, C. A novel saliva-based microRNA biomarker panel to detect head and neck cancers. Cell. Oncol. 2014, 37, 331-338. [CrossRef] [PubMed]

88. Takeshita, N.; Hoshino, I.; Mori, M.; Akutsu, Y.; Hanari, N.; Yoneyama, Y.; Ikeda, N.; Isozaki, Y.; Maruyama, T.; Akanuma, N.; et al. Serum microRNA expression profile: miR-1246 as a novel diagnostic and prognostic biomarker for oesophageal squamous cell carcinoma. Br. J. Cancer 2013, 108, 644-652. [CrossRef] [PubMed]

89. Wang, K.; Yuan, Y.; Cho, J.-H.; McClarty, S.; Baxter, D.; Galas, D.J. Comparing the microRNA spectrum between serum and plasma. PLoS ONE 2012, 7, e41561. [CrossRef] [PubMed]

90. Wang, L.; Lv, J.; Guo, C.; Li, H.; Xiong, C. Recovery of cell-free mRNA and microRNA from human semen based on their physical nature. Biotechnol. Appl. Biochem. 2014, 61, 342-348. [CrossRef] [PubMed]

91. Yang, Y.; Li, Y.-X.; Yang, X.; Jiang, L.; Zhou, Z.-J.; Zhu, Y.-Q. Progress risk assessment of oral premalignant lesions with saliva miRNA analysis. BMC Cancer 2013, 13, 129. [CrossRef] [PubMed]

92. Chen, X.; Liang, H.; Zhang, C.-Y.; Zhang, J.; Zen, K. Secreted microRNAs: A new form of intercellular communication. Trends Cell Biol. 2012, 22, 125-132. [CrossRef] [PubMed]

93. Valadi, H.; Sjöstrand, M.; Bossios, A.; Ekström, K.; Lee, J.J.; Lötvall, J.O.; Sahlgrenska, A.; Sahlgrenska, A. Exosome-mediated transfer of mRNAs and microRNAs is a novel mechanism of genetic exchange between cells. Nat. Cell Biol. 2007, 9, 654-659. [CrossRef] [PubMed]

94. Corsten, M.F.; Dennert, R.; Jochems, S.; Kuznetsova, T.; Devaux, Y.; Hofstra, L.; Wagner, D.R.; Staessen, J.A.; Heymans, S.; Schroen, B. Circulating microRNA-208b and microRNA-499 reflect myocardial damage in cardiovascular disease. Circ.: Cardiovasc. Genet. 2010, 3, 499-506. [CrossRef] [PubMed]

95. Pritchard, C.C.; Kroh, E.; Wood, B.; Arroyo, J.D.; Dougherty, K.J.; Miyaji, M.M.; Tait, J.F.; Tewari, M. Blood cell origin of circulating microRNAs: A cautionary note for cancer biomarker studies. Cancer Prev. Res. 2012, 5, 492-497. [CrossRef] [PubMed]

96. Turchinovich, A.; Weiz, L.; Langheinz, A.; Burwinkel, B. Characterization of extracellular circulating microRNA. Nucleic Acids Res. 2011, 139, 7223-7233. [CrossRef] [PubMed]

97. Cortez, M.A.; Bueso-Ramos, C.; Ferdin, J.; Lopez-Berestein, G.; Sood, A.K.; Calin, G.A. MicroRNAs in body fluid-the mix of hormones and biomarkers. Nat. Rev. Clin. Oncol. 2011, 8, 467-477. [CrossRef] [PubMed]

98. Harding, C.; Heuser, J.; Stahl, P. Receptor-mediated endocytosis of transferrin and recycling of the transferrin receptor in rat reticulocytes. J. Cell Biol. 1983, 97, 329-339. [CrossRef] [PubMed]

99. Raposo, G.; Stoorvogel, W. Extracellular vesicles: Exosomes, microvesicles, and friends. J. Cell Biol. 2013, 200, 373-383. [CrossRef] [PubMed]

100. Wollert, T.; Hurley, J.H. Molecular mechanism of multivesicular body biogenesis by ESCRT complexes. Nature 2010, 464, 864-869. [CrossRef] [PubMed]

101. Lee, Y.; Andaloussi, S.E.; Wood, M.J. Exosomes and microvesicles: Extracellular vesicles for genetic information transfer and gene therapy. Hum. Mol. Genet. 2012, 21, R125-R134. [CrossRef] [PubMed]

102. Raposo, G.; Nijman, H.W.; Stoorvogel, W.; Liejendekker, R.; Harding, C.V.; Melief, C.J.; Geuze, H.J. B lymphocytes secrete antigen-presenting vesicles. J. Exp. Med. 1996, 183, 1161-1172. [CrossRef] [PubMed]

103. Bobrie, A.; Colombo, M.; Raposo, G.; Théry, C. Exosome secretion: Molecular mechanisms and roles in immune responses. Traffic 2011, 12, 1659-1668. [CrossRef] [PubMed]

104. Hunter, M.P.; Ismail, N.; Zhang, X.; Aguda, B.D.; Lee, E.J.; Yu, L.; Xiao, T.; Schafer, J.; Lee, M.L.; Schmittgen, T.D.; et al. Detection of microRNA expression in human peripheral blood microvesicles. PLoS ONE 2008, 3, e3694. [CrossRef] [PubMed] 
105. Michael, A.; Bajracharya, S.D.; Yuen, P.S.; Zhou, H.; Star, R.A.; Illei, G.G.; Alevizos, I. Exosomes from human saliva as a source of microRNA biomarkers. Oral Dis. 2010, 16, 34-38. [CrossRef] [PubMed]

106. Rabinowits, G.; Gercel-Taylor, C.; Day, J.M.; Taylor, D.D.; Kloecker, G.H. Exosomal microRNA: A diagnostic marker for lung cancer. Clin. Lung Cancer 2009, 10, 42-46. [CrossRef] [PubMed]

107. Skog, J.; Wurdinger, T.; van Rijn, S.; Meijer, D.H.; Gainche, L.; Sena-Esteves, M.; Curry, W.T., Jr.; Carter, B.S.; Krichevsky, A.M.; Breakefield, X.O. Glioblastoma microvesicles transport RNA and proteins that promote tumour growth and provide diagnostic biomarkers. Nat. Cell Biol. 2008, 10, 1470-1476. [CrossRef] [PubMed]

108. Nolte-'t Hoen, E.N.; Buermans, H.P.; Waasdorp, M.; Stoorvogel, W.; Wauben, M.H.; Hoen, P.A. Deep sequencing of RNA from immune cell-derived vesicles uncovers the selective incorporation of small non-coding RNA biotypes with potential regulatory functions. Nucleic Acids Res. 2012, 40, 9272-9285. [CrossRef] [PubMed]

109. Batagov, A.O.; Kuznetsov, V.A.; Kurochkin, I.V. Identification of nucleotide patterns enriched in secreted RNAs as putative cis-acting elements targeting them to exosome nano-vesicles. BMC Genom. 2011. [CrossRef] [PubMed]

110. Villarroya-Beltri, C.; Gutierrez-Vazquez, C.; Sanchez-Cabo, F.; Perez-Hernandez, D.; Vazquez, J.; Martin-Cofreces, N.; Martinez-Herrera, D.J.; Pascual-Montano, A.; Mittelbrunn, M.; Sanchez-Madrid, F. Sumoylated hnRNPA2B1 controls the sorting of miRNAs into exosomes through binding to specific motifs. Nat. Commun. 2013. [CrossRef] [PubMed]

111. Gibbings, D.J.; Ciaudo, C.; Erhardt, M.; Voinnet, O. Multivesicular bodies associate with components of miRNA effector complexes and modulate miRNA activity. Nat. Cell Biol. 2009, 11, 1143-1149. [CrossRef] [PubMed]

112. Denzer, K.; van Eijk, M.; Kleijmeer, M.J.; Jakobson, E.; de Groot, C.; Geuze, H.J. Follicular dendritic cells carry MHC class II-expressing microvesicles at their surface. J. Immunol. 2000, 165, 1259-1265. [CrossRef] [PubMed]

113. Mallegol, J.; van Niel, G.; Lebreton, C.; Lepelletier, Y.; Candalh, C.; Dugave, C.; Heath, J.K.; Raposo, G.; Cerf-Bensussan, N.; Heyman, M. T84-intestinal epithelial exosomes bear MHC class II/peptide complexes potentiating antigen presentation by dendritic cells. Gastroenterology 2007, 132, 1866-1876. [CrossRef] [PubMed]

114. Buschow, S.I.; van Niel, G.; Pols, M.S.; Ten Broeke, T.; Lauwen, M.; Ossendorp, F.; Melief, C.J.; Raposo, G.; Wubbolts, R.; Wauben, M.H. MHC II in dendritic cells is targeted to lysosomes or T cell-induced exosomes via distinct multivesicular body pathways. Traffic 2009, 10, 1528-1542. [CrossRef] [PubMed]

115. Rana, S.; Yue, S.; Stadel, D.; Zöller, M. Toward tailored exosomes: The exosomal tetraspanin web contributes to target cell selection. Int. J. Biochem. Cell Biol. 2012, 44, 1574-1584. [CrossRef] [PubMed]

116. Barrès, C.; Blanc, L.; Bette-Bobillo, P.; André, S.; Mamoun, R.; Gabius, H.-J.; Vidal, M. Galectin-5 is bound onto the surface of rat reticulocyte exosomes and modulates vesicle uptake by macrophages. Blood 2010, 115, 696-705. [CrossRef] [PubMed]

117. Reid, G.; Kirschner, M.B.; van Zandwijk, N. Circulating microRNAs: Association with disease and potential use as biomarkers. Crit. Rev. Oncol./Hematol. 2011, 80, 193-208. [CrossRef] [PubMed]

118. Kirschner, M.B.; Kao, S.C.; Edelman, J.J.; Armstrong, N.J.; Vallely, M.P.; van Zandwijk, N.; Reid, G. Haemolysis during sample preparation alters microRNA content of plasma. PLoS ONE 2011, 6, e24145. [CrossRef] [PubMed]

119. McDonald, J.S.; Milosevic, D.; Reddi, H.V.; Grebe, S.K.; Algeciras-Schimnich, A. Analysis of circulating microRNA: Preanalytical and analytical challenges. Clin. Chem. 2011, 57, 833-840. [CrossRef] [PubMed]

120. García, M.E.; Blanco, J.L.; Caballero, J.; Gargallo-Viola, D. Anticoagulants interfere with PCR used to diagnose invasive aspergillosis. J. Clin. Microbial. 2002, 40, 1567-1568. [CrossRef]

121. Willems, M.; Moshage, H.; Nevens, F.; Fevery, J.; Yap, S.H. Plasma collected from heparinized blood is not suitable for HCV-RNA detection by conventional RT-PCR assay. J. Virol. Methods 1993, 42, 127-130. [CrossRef]

122. Zhao, H.; Shen, J.; Hu, Q.; Davis, W.; Medico, L.; Wang, D.; Yan, L.; Guo, Y.; Liu, B.; Qin, M. Effects of preanalytic variables on circulating microRNAs in whole blood. Cancer Epidemiol. Biomark. Prev. 2014, 23, 2643-2648. [CrossRef] [PubMed] 
123. El-Khoury, V.; Pierson, S.; Kaoma, T.; Bernardin, F.; Berchem, G. Assessing cellular and circulating miRNA recovery: The impact of the RNA isolation method and the quantity of input material. Sci. Rep. 2016. [CrossRef] [PubMed]

124. Hand, N.J.; Master, Z.R.; Le Lay, J.; Friedman, J.R. Hepatic function is preserved in the absence of mature microRNAs. Hepatology 2009, 49, 618-626. [CrossRef] [PubMed]

125. Bihrer, V.; Friedrich-Rust, M.; Kronenberger, B.; Forestier, N.; Haupenthal, J.; Shi, Y.; Peveling-Oberhag, J.; Radeke, H.H.; Sarrazin, C.; Herrmann, E. Serum miR-122 as a biomarker of necroinflammation in patients with chronic hepatitis C virus infection. Am. J. Gastroenterol. 2011, 106, 1663-1669. [CrossRef] [PubMed]

126. Qu, K.Z.; Zhang, K.; Li, H.; Afdhal, N.H.; Albitar, M. Circulating microRNAs as biomarkers for hepatocellular carcinoma. J. Clin. Gastroenterol. 2011, 45, 355-360. [CrossRef] [PubMed]

127. Bessho, K.; Shanmukhappa, K.; Sheridan, R.; Shivakumar, P.; Mourya, R.; Walters, S.; Kaimal, V.; Dilbone, E.; Jegga, A.G.; Bezerra, J.A. Integrative genomics identifies candidate microRNAs for pathogenesis of experimental biliary atresia. BMC Syst. Biol. 2013, 7, 104. [CrossRef] [PubMed]

128. Xiao, Y.; Wang, J.; Chen, Y.; Zhou, K.; Wen, J.; Wang, Y.; Zhou, Y.; Pan, W.; Cai, W. Up-regulation of miR-200b in biliary atresia patients accelerates proliferation and migration of hepatic stallate cells by activating Pi3k/AKT signaling. Cell Signal. 2014, 26, 925-932. [CrossRef] [PubMed]

129. Shen, W.; Chen, G.; Dong, R.; Zhao, R.; Zheng, S. MicroRNA-21/PTEN/AKT axis in the fibrogenesis of biliary atresia. J. Pediatr. Surg. 2014, 49, 1738-1741. [CrossRef] [PubMed]

130. Hand, N.J.; Horner, A.M.; Master, Z.R.; Boateng, L.A.; LeGuen, C.; Uvaydova, M.; Friedman, J.R. MicroRNA profiling identifies miR-29 as a regulator of disease-associated pathways in experimental biliary atresia. J. Pediatr. Gastroenterol. Nutr. 2012, 54, 186. [CrossRef] [PubMed]

131. Shen, W.-J.; Dong, R.; Chen, G.; Zheng, S. MicroRNA-222 modulates liver fibrosis in a murine model of biliary atresia. Biochem. Biophys. Res. Commun. 2014, 446, 155-159. [CrossRef] [PubMed]

132. Dong, R.; Zheng, Y.; Chen, G.; Zhao, R.; Zhou, Z.; Zheng, S. MiR-222 overexpression may contribute to liver fibrosis in biliary atresia by targeting PPP2R2A. J. Pediatr. Gastroenterol. Nutr. 2015, 60, 84-90. [CrossRef] [PubMed]

133. Hu, G.; Gong, A.-Y.; Liu, J.; Zhou, R.; Deng, C.; Chen, X.-M. MiR-221 suppresses ICAM-1 translation and regulates interferon- $\gamma$-induced ICAM-1 expression in human cholangiocytes. Am. J. Physiol.-Gastrointest. Liver Physiol. 2010, 298, 542-550. [CrossRef] [PubMed]

134. Xiao, Y.; Wang, J.; Yan, W.; Zhou, Y.; Chen, Y.; Zhou, K.; Wen, J.; Wang, Y.; Cai, W. Dysregulated miR-124 and miR-200 expression contribute to cholangiocyte proliferation in the cholestatic liver by targeting IL-6/STAT3 signalling. J. Hepatol. 2015, 62, 889-896. [CrossRef] [PubMed]

135. Yu, D.S.; An, F.M.; Gong, B.D.; Xiang, X.G.; Lin, L.Y.; Wang, H.; Xie, Q. The regulatory role of microRNA-1187 in TNF- $\alpha$-mediated hepatocyte apoptosis in acute liver failure. Int. J. Mol. Med. 2012, 29, 663-668. [PubMed]

136. An, F.; Gong, B.; Wang, H.; Yu, D.; Zhao, G.; Lin, L.; Tang, W.; Yu, H.; Bao, S.; Xie, Q. miR-15b and miR-16 regulate TNF mediated hepatocyte apoptosis via $\mathrm{Bcl} 2$ in acute liver failure. Apoptosis 2012, 17, 702-716. [CrossRef] [PubMed]

137. Salehi, S.; Brereton, H.C.; Arno, M.J.; Darling, D.; Quaglia, A.; O'Grady, J.; Heaton, N.; Aluvihare, V.R. Human liver regeneration is characterized by the coordinated expression of distinct microRNA governing cell cycle fate. Am. J. Transpl. 2013, 13, 1282-1295. [CrossRef] [PubMed]

138. Hur, W.; Lee, J.H.; Kim, S.W.; Kim, J.-H.; Bae, S.H.; Kim, M.; Hwang, D.; Kim, Y.S.; Park, T.; Um, S.-J. Downregulation of microRNA-451 in non-alcoholic steatohepatitis inhibits fatty acid-induced proinflammatory cytokine production through the AMPK/AKT pathway. Int. J. Biochem. Cell Biol. 2015, 64, 265-276. [CrossRef] [PubMed]

139. Feng, Y.Y.; Xu, X.Q.; Ji, C.B.; Shi, C.M.; Guo, X.R.; Fu, J.F. Aberrant hepatic microRNA expression in nonalcoholic fatty liver disease. Cell. Physiol. Biochem. 2014, 34, 1983-1997. [CrossRef] [PubMed]

140. Dattaroy, D.; Pourhoseini, S.; Das, S.; Alhasson, F.; Seth, R.K.; Nagarkatti, M.; Michelotti, G.A.; Diehl, A.M.; Chatterjee, S. Micro-RNA 21 inhibition of SMAD7 enhances fibrogenesis via leptin-mediated NADPH oxidase in experimental and human nonalcoholic steatohepatitis. Am. J. Physiol. 2015, 308, 298-312. [CrossRef] [PubMed]

141. Israelow, B.; Mullokandov, G.; Agudo, J.; Sourisseau, M.; Bashir, A.; Maldonado, A.Y.; Dar, A.C.; Brown, B.D.; Evans, M.J. Hepatitis $C$ virus genetics affects miR-122 requirements and response to miR-122 inhibitors. Nat. Commun. 2014, 5, 5408. [CrossRef] [PubMed] 
142. Lindblad, A.; Glaumann, H.; Strandvik, B. Natural history of liver disease in cystic fibrosis. Hepatology 1999, 30, 1151-1158. [CrossRef] [PubMed]

143. Cook, N.L.; Pereira, T.N.; Lewindon, P.J.; Shepherd, R.W.; Ramm, G.A. Circulating microRNAs as non-invasive diagnostic biomarkers of liver disease in children with cystic fibrosis. J. Pediatr. Gastroenterol. Nutr. 2014, 60, 247-254. [CrossRef] [PubMed]

144. Zahm, A.M.; Hand, N.J.; Boateng, L.A.; Friedman, J.R. Circulating microRNA is a biomarker of biliary atresia. J. Pediatr. Gastroenterol. Nutr. 2012, 55, 366-369. [CrossRef] [PubMed]

145. Dong, R.; Shen, Z.; Zheng, C.; Chen, G.; Zheng, S. Serum microRNA microarray analysis identifies miR-4429 and miR-4689 are potential diagnostic biomarkers for biliary atresia. Sci. Rep. 2016. [CrossRef] [PubMed]

146. Peng, X.; Yang, L.; Liu, H.; Pang, S.; Chen, Y.; Fu, J.; Chen, Y.; Wen, Z.; Zhang, R.; Zhu, B.; et al. Identification of circulating microRNAs in biliary atresia by next-generation sequencing. J. Pediatr. Gastroenterol. Nutr. 2016, in press. [CrossRef] [PubMed]

147. Winther, T.N.; Bang-Berthelsen, C.H.; Heiberg, I.L.; Pociot, F.; Hogh, B. Differential plasma microRNA profiles in HBeAg positive and HBeAg negative children with chronic hepatitis B. PLoS ONE 2013, 8, e58236. [CrossRef] [PubMed]

148. Winther, T.N.; Heiberg, I.L.; Bang-Berthelsen, C.H.; Pociot, F.; Hogh, B. Hepatitis B surface antigen quantity positively correlates with plasma levels of microRNAs differentially expressed in immunological phases of chronic hepatitis B in children. PLoS ONE 2013, 8, e80384. [CrossRef] [PubMed]

149. Winther, T.N.; Jacobsen, K.S.; Mirza, A.H.; Heiberg, I.L.; Bang-Berthelsen, C.H.; Pociot, F.; Hogh, B. Circulating microRNAs in plasma of hepatitis B e antigen positive children reveal liver-specific target genes. Int. J. Hepatol. 2014. [CrossRef] [PubMed]

150. Smith, J.L.; Lewindon, P.J.; Hoskins, A.C.; Pereira, T.N.; Setchell, K.D.R.; O'Connell, N.C.; Shepherd, R.W.; Ramm, G.A. Endogenous ursodeoxycholic acid and cholic acid in liver disease due to cystic fibrosis. Hepatology 2004, 39, 1673-1682. [CrossRef] [PubMed]

151. Lewindon, P.J.; Pereira, T.N.; Hoskins, A.C.; Bridle, K.R.; Williamson, R.M.; Shepherd, R.W.; Ramm, G.A. The role of hepatic stellate cells and transforming growth factor- $\beta 1$ in cystic fibrosis liver disease. Am. J. Pathol. 2002, 160, 1705-1715. [CrossRef]

152. Lu, Z.; Liu, M.; Stribinskis, V.; Klinge, C.; Ramos, K.; Colburn, N.; Li, Y. MicroRNA-21 promotes cell transformation by targeting the programmed cell death 4 gene. Oncogene 2008, 27, 4373-4379. [CrossRef] [PubMed]

153. Li, X.; Huang, K.; Yu, J. Inhibition of microRNA-21 upregulates the expression of programmed cell death 4 and phosphatase tensin homologue in the a431 squamous cell carcinoma cell line. Oncol. Lett. 2014, 8 , 203-207. [PubMed]

154. Zhang, J.; Jiao, J.; Cermelli, S.; Muir, K.; Jung, K.H.; Zou, R.; Rashid, A.; Gagea, M.; Zabludoff, S.; Kalluri, R.; et al. miR-21 inhibition reduces liver fibrosis and prevents tumor development by inducing apoptosis of CD24+ progenitor cells. Cancer Res. 2015. [CrossRef] [PubMed]

155. Rodrigues, P.M.; Afonso, M.B.; Simao, A.L.; Borralho, P.M.; Rodrigues, C.M.P.; Castro, R.E. Inhibition of NF-kB by deoxycholic acid induces miR-21/PDCD4-dependent hepatocelular apoptosis. Sci. Rep. 2015. [CrossRef] [PubMed]

156. Castro, R.E.; Ferreira, D.M.; Zhang, X.; Borralho, P.M.; Sarver, A.L.; Zeng, Y.; Steer, C.J.; Kren, B.T.; Rodrigues, C.M. Identification of microRNAs during rat liver regeneration after partial hepatectomy and modulation by ursodeoxycholic acid. American journal of physiology. Gastrointest. Liver Physiol. 2010, 299, G887-G897. [CrossRef] [PubMed]

157. Razumilava, N.; Bronk, S.F.; Smoot, R.L.; Fingas, C.D.; Werneburg, N.W.; Roberts, L.R.; Mott, J.L. miR-25 targets TNF-related apoptosis inducing ligand (TRAIL) death receptor-4 and promotes apoptosis resistance in cholangiocarcinoma. Hepatology 2012, 55, 465-475. [CrossRef] [PubMed]

158. Uziel, T.; Karginov, F.V.; Xie, S.; Parker, J.S.; Wang, Y.D.; Gajjar, A.; He, L.; Ellison, D.; Gilbertson, R.J.; Hannon, G.; et al. The miR-17-92 cluster collaborates with the sonic hedgehog pathway in medulloblastoma. Proc. Natl. Acad. Sci. USA 2009, 106, 2812-2817. [CrossRef] [PubMed]

159. Hartley, J.L.; Davenport, M.; Kelly, D.A. Biliary atresia. Lancet 2009, 374, 1704-1713. [CrossRef]

160. Sokol, R.J.; Shepherd, R.W.; Superina, R.; Bezerra, J.A.; Robuck, P.; Hoofnagle, J.H. Screening and outcomes in biliary atresia: Summary of a national institutes of health workshop. Hepatology 2007, 46, 566-581. [CrossRef] [PubMed] 
161. Ramm, G.A.; Nair, V.G.; Bridle, K.R.; Shepherd, R.W.; Crawford, D.H. Contribution of hepatic parenchymal and nonparenchymal cells to hepatic fibrogenesis in biliary atresia. Am. J. Pathol. 1998, 153, 527-535. [CrossRef]

162. Tang, X.; Hou, Y.; Yang, G.; Wang, X.; Tang, S.; Du, Y.E.; Yang, L.; Yu, T.; Zhang, H.; Zhou, M.; et al. Stromal miR-200s contribute to breast cancer cell invasion through caf activation and ecm remodeling. Cell Death Differ. 2016, 23, 132-145. [CrossRef] [PubMed]

163. Fang, L.; Ellims, A.H.; Moore, X.-L.; White, D.A.; Taylor, A.J.; Chin-Dusting, J.; Dart, A.M. Circulating microRNAs as biomarkers for diffuse myocardial fibrosis in patients with hypertrophic cardiomyopathy. J. Transl. Med. 2015, 13, 314. [CrossRef] [PubMed]

164. Wang, B.; Koh, P.; Winbanks, C.; Coughlan, M.T.; McClelland, A.; Watson, A.; Jandeleit-Dahm, K.; Burns, W.C.; Thomas, M.C.; Cooper, M.E.; et al. miR-200a prevents renal fibrogenesis through repression of TGF-2 expression. Diabetes 2011, 60, 280-287. [CrossRef] [PubMed]

165. Yang, S.; Banerjee, S.; de Freitas, A.; Sanders, Y.Y.; Ding, Q.; Matalon, S.; Thannickal, V.J.; Abraham, E.; Liu, G. Participation of miR-200 in pulmonary fibrosis. Am. J. Pathol. 2012, 180, 484-493. [CrossRef] [PubMed]

166. Gregory, P.A.; Bracken, C.P.; Smith, E.; Bert, A.G.; Wright, J.A.; Roslan, S.; Morris, M.; Wyatt, L.; Farshid, G.; Lim, Y.-Y.; et al. An autocrine TGF- $\beta / Z E B / m i R-200$ signaling network regulates establishment and maintenance of epithelial-mesenchymal transition. Mol. Biol. Cell 2011, 22, 1686-1698. [CrossRef] [PubMed]

167. Xiong, M.; Jiang, L.; Zhou, Y.; Qiu, W.; Fang, L.; Tan, R.; Wen, P.; Yang, J. The miR-200 family regulates TGF- $\beta 1$-induced renal tubular epithelial to mesenchymal transition through SMAD pathway by targeting ZEB1 and ZEB2 expression. Am. J. Physiol. Ren. Physiol. 2012, 302, F369-F379. [CrossRef] [PubMed]

168. Gregory, P.A. The miR-200 family and miR-205 regulate epithelial to mesenchymal transition by targeting ZEB1 and SIP1. Nat. Cell Biol. 2008, 10, 593-601. [CrossRef] [PubMed]

169. Chen, Y.; Ge, W.; Xu, L.; Qu, C.; Zhu, M.; Zhang, W.; Xiao, Y. miR-200b is involved in intestinal fibrosis of crohn's disease. Int. J. Mol. Med. 2012, 29, 601-606. [PubMed]

170. Ott, J.J.; Stevens, G.A.; Groeger, J.; Wiersma, S.T. Global epidemiology of hepatitis B virus infection: New estimates of age-specific HBsAg seroprevalence and endemicity. Vaccine 2012, 30, 2212-2219. [CrossRef] [PubMed]

171. Lok, A.S.F.; McMahon, B.J. Chronic hepatitis B: Update 2009. Hepatology 2009, 50, 661-662. [CrossRef] [PubMed]

172. Gish, R.G.; Given, B.D.; Lai, C.-L.; Locarnini, S.A.; Lau, J.Y.N.; Lewis, D.L.; Schluep, T. Chronic hepatitis B: Virology, natural history, current management and a glimpse at future opportunities. Antivir. Res. 2015, 121, 47-58. [CrossRef] [PubMed]

173. European Association for the Study of the Liver. Easl clinical practice guidelines: Management of chronic hepatitis B virus infection. J. Hepatol. 2012, 57, 167-185.

174. Conner, E.A.; Lemmer, E.R.; Omori, M.; Wirth, P.J.; Factor, V.M.; Thorgeirsson, S.S. Dual functions of E2F-1 in a transgenic mouse model of liver carcinogenesis. Oncogene 2000, 19, 5054-5062. [CrossRef] [PubMed]

175. Heise, T.; Sommer, G.; Reumann, K.; Meyer, I.; Will, H.; Schaal, H. The hepatitis B virus pre contains a splicing regulatory element. Nucleic Acids Res. 2006, 34, 353-363. [CrossRef] [PubMed]

176. Huang, J.; Deng, Q.; Wang, Q.; Li, K.-Y.; Dai, J.-H.; Li, N.; Zhu, Z.-D.; Zhou, B.; Liu, X.-Y.; Liu, R.-F.; et al. Exome sequencing of hepatitis B virus-associated hepatocellular carcinoma. Nat. Genet. 2012. [CrossRef] [PubMed]

177. Sun, T.-P.; Shieh, S.-Y.; Ou, Y.-H.; Chung, P.-H.; Chang, W.-Y.; Hsu, F.-F. The candidate tumor suppressor BTG3 is a transcriptional target of p53 that inhibits E2F1. EMBO J. 2007, 26, 3968-3980.

178. Trehanpati, N.; Shrivastav, S.; Shivakumar, B.; Khosla, R.; Bhardwaj, S.; Chaturvedi, J.; Sukriti; Kumar, B.; Bose, S.; Mani Tripathi, D.; et al. Analysis of NOTCH and TGF- $\beta$ signaling expression in different stages of disease progression during hepatitis B virus infection. Clin. Transl. Gastroenterol. 2012. [CrossRef] [PubMed]

179. Ninomiya, M.; Kondo, Y.; Kimura, O.; Funayama, R.; Nagashima, T.; Kogure, T.; Morosawa, T.; Tanaka, Y.; Nakayama, K.; Shimosegawa, T. The expression of miR-125b-5p is increased in the serum of patients with chronic hepatitis B infection and inhibits the detection of hepatitis B virus surface antigen. J. Viral Hepat. 2016, 23, 330-339. [CrossRef] [PubMed]

180. Della Corte, C.; Mosca, A.; Vania, A.; Alterio, A.; Alisi, A.; Nobili, V. Pediatric liver diseases: Current challenges and future perspectives. Expert Rev. Gastroenterol. Hepatol. 2016, 10, 255-265. [CrossRef] [PubMed] 
181. Iwakawa, H.-O.; Tomari, Y. The functions of microRNAs: mRNA decay and translational repression. Trends Cell Biol. 2015, 25, 651-665. [CrossRef] [PubMed]

182. Hausser, J.; Zavolan, M. Identification and consequences of miRNA-target interactions-Beyond repression of gene expression. Nat. Rev. Genet. 2014, 15, 599-612. [CrossRef] [PubMed]

183. Arroyo, J.D.; Chevillet, J.R.; Kroh, E.M.; Ruf, I.K.; Pritchard, C.C.; Gibson, D.F.; Mitchell, P.S.; Bennett, C.F.; Pogosova-Agadjanyan, E.L.; Stirewalt, D.L.; et al. Argonaute2 complexes carry a population of circulating microRNAs independent of vesicles in human plasma. Proc. Natl. Acad. Sci. USA 2011, 108, 5003-5008. [CrossRef] [PubMed]

184. Zernecke, A.; Bidzhekov, K.; Noels, H.; Shagdarsuren, E.; Gan, L.; Denecke, B.; Hristov, M.; Koppel, T.; Jahantigh, M.N.; Lutgens, E.; et al. Delivery of microRNA-126 by apoptotic bodies induces CXCL12-dependent vascular protection. Sci. Signal. 2009, 2. [CrossRef] [PubMed]

185. Vickers, K.C.; Palmisano, B.T.; Shoucri, B.M.; Shamburek, R.D.; Remaley, A.T. MicroRNAs are transported in plasma and delivered to recipient cells by high-density lipoproteins. Nat. Cell Biol. 2011, 13, 423-433. [CrossRef] [PubMed]

186. Hou, J.; Lin, L.; Zhou, W.; Wang, Z.; Ding, G.; Dong, Q.; Qin, L.; Wu, X.; Zheng, Y.; Yang, Y.; et al. Identification of miRNomes in human liver and hepatocellular carcinoma reveals miR-199a/b-3p as therapeutic target for hepatocellular carcinoma. Cancer Cell 2011, 19, 232-243. [CrossRef] [PubMed]

187. Anderson, E.L.; Howe, L.D.; Jones, H.E.; Higgins, J.P.T.; Lawlor, D.A.; Fraser, A. The prevalence of non-alcoholic fatty liver disease in children and adolescents: A systematic review and meta-analysis. PLoS ONE 2015, 10, e0140908. [CrossRef] [PubMed]

188. Schwimmer, J.B.; Newton, K.P.; Awai, H.I.; Choi, L.J.; Garcia, M.A.; Ellis, L.L.; Vanderwall, K.; Fontanesi, J. Paediatric gastroenterology evaluation of overweight and obese children referred from primary care for suspected non-alcoholic fatty liver disease. Aliment. Pharmacol. Ther. 2013, 38, 1267-1277. [CrossRef] [PubMed]

(C) 2016 by the authors; licensee MDPI, Basel, Switzerland. This article is an open access article distributed under the terms and conditions of the Creative Commons Attribution (CC-BY) license (http://creativecommons.org/licenses/by/4.0/). 